\title{
Geochemistry and mineralogy of the phonolite lava lake, Erebus volcano, Antarctica: 1972 - 2004 and comparison with older lavas
}

\author{
Peter J. Kelly ${ }^{\mathrm{a}, 1}$, Philip R. Kyle ${ }^{\mathrm{a}}$, Nelia W. Dunbar ${ }^{\mathrm{b}}$, Kenneth W.W. Sims ${ }^{\mathrm{c}}$ \\ ${ }^{a}$ Department of Earth and Environmental Science,New Mexico Institute of Mining and \\ Technology, Socorro, NM 87801-4796 \\ ${ }^{\mathrm{b}}$ New Mexico Bureau of Geology and Mineral Resources, New Mexico Institute of Mining and \\ Technology, Socorro, NM 87801-4796 \\ ${ }^{\mathrm{c}}$ Woods Hole Oceanographic Institution, Woods Hole, MA, Woods Hole, 02543 \\ ${ }^{1}$ Current address: \\ Climate Change Research Center, University of New Hampshire, Durham, NH 03824-3525 \\ Corresponding author: \\ Peter Kelly \\ Climate Change Research Center, University of New Hampshire \\ 39 College Rd. \\ Durham, NH 03824 \\ E-mail: p.kelly@unh.edu \\ Fax: 603-862-2124
}

For submission to Special Issue on Erebus Volcano, Journal of Volcanology and Geothermal Research

14 October 2007

Word Counts:

Abstract: 258

Text: 7,417

Figure Captions: 691

Table Captions: 109

References: 91

Figures: 10

Tables: 5

Keywords: Erebus volcano; phonolite; lava bombs; mineralogy; geochemistry; Antarctica 


\begin{abstract}
Mount Erebus, Antarctica, is a large (3794 m) alkaline open-conduit stratovolcano that hosts a vigorously convecting and persistently degassing lake of anorthoclase phonolite magma. The composition of the lake was investigated by analyzing glass and mineral compositions in lava bombs erupted between 1972 and 2004. Matrix glass, titanomagnetite, olivine, clinopyroxene, and fluor-apatite compositions are invariant and show that the magmatic temperature $\left(\sim 1000^{\circ} \mathrm{C}\right)$ and oxygen fugacity $(\Delta \operatorname{logFMQ}=-0.9)$ have been stable. Large temperature variations at the lake surface $\left(\mathrm{ca} .400-500^{\circ} \mathrm{C}\right)$ are not reflected in mineral compositions. Anorthoclase phenocrysts up to $10 \mathrm{~cm}$ in length feature a restricted compositional range $\left(\mathrm{An}_{10.3-22.9} \mathrm{Ab}_{62.8-68.1} \mathrm{Or}_{11.4-27.2}\right)$ with complex textural and compositional zoning. Anorthoclase textures and compositions indicate crystallization occurs at low degrees of effective undercooling. We propose shallow water exsolution causes crystallization to occur and shallow convection repeats this process multiple times, yielding extremely large anorthoclase crystals. Minor variations in eruptive activity from 1972 to 2004 are decoupled from magma compositions. The variations probably relate to changes in conduit geometry within the volcano and/or variable input of $\mathrm{CO}_{2}$-rich volatiles into the upper-level magma chamber from deeper in the system.
\end{abstract}

Eleven bulk samples of phonolite lava from the summit plateau that range in age from $0 \pm$ $4 \mathrm{ka}$ to $17 \pm 8 \mathrm{ka}$ were analyzed for major and trace elements. Small compositional variations are controlled by anorthoclase content. The lavas are indistinguishable from modern bulk lava bomb compositions and demonstrate that Erebus volcano has been erupting lava and tephra from the summit region with the same bulk composition for $\sim 17 \mathrm{ka}$. 


\section{Introduction}

Erebus volcano, Antarctica, (Fig. 1) is a large (3794 m) open-conduit stratovolcano that hosts a vigorously convecting and persistently degassing lake of anorthoclase-rich (30 - 40 vol.\%) phonolite magma. The lake was first directly observed by a scientific party in 1972 (Giggenbach et al., 1973; Kyle et al., 1982) and is exceptional because it offers a direct view into an active upper-level magma chamber. Since 1972 the lake has always been present but has changed in size (5 - $60 \mathrm{~m}$ diameter), shape, and location (Kyle et al., 1982; Aster et al., 2003). Year-round real time monitoring of the volcano is provided by an array of geophysical instruments (Aster et al., 2004; http://erebus.nmt.edu).

Frequent Strombolian eruptions (up to $\sim 6$ per day) from the lake are a characteristic feature of Erebus volcano. Eruptions occur when a large gas slug rapidly rises from depth and bursts at the lake surface. The eruptions often eject lava bombs onto the crater rim and thus provide samples to examine the composition of magma in the lake. Fresh lava bombs have been collected by scientific field parties nearly every austral summer from 1972 to the present. The accumulated sample suite represents a 35-year quenched record of magma composition in the lake.

In this study we present: (1) new major and trace element compositions of glass and minerals from 38 lava bombs erupted from Erebus volcano between 1972 to 2004, and (2) new major and trace element whole rock compositions of 11 lavas erupted from the summit region in the last $\sim 17 \mathrm{ka}$. Geochemical data from the recently erupted lava bombs are used to document the composition of magma in the lake from 1972 to 2004, constrain intensive parameters, and probe crystallization processes within the shallow magmatic system. A comparison is made between the composition of recently erupted lava bombs and older lavas to understand magma 
composition over a longer time. Companion studies (Sims et al., 2008a, b) document the corresponding radiogenic isotope signatures $(\mathrm{Nd}, \mathrm{Hf}, \mathrm{Sr}, \mathrm{Pb})$ and $\mathrm{U}$-series isotopes of these and other samples to constrain the mantle source characteristics and long and short-term (1.3 Mapresent) evolution of Erebus lavas.

\section{Erebus Volcano}

\subsection{Volcanic geology}

Erebus volcano is the southernmost active volcano in the world. Intracontinental rifting and extension have resulted in voluminous alkaline volcanism in the western Ross Sea, termed the McMurdo Volcanic Group (Kyle and Cole, 1974; Kyle, 1990a). On Ross Island, Mt. Erebus and its subsidiary volcanic centers, Mt. Terror, Mt. Bird, and Hut Point Peninsula (Fig. 1) form part of the Erebus volcanic province (Kyle, 1990b). Ross Island overlies very thin (17 - $25 \mathrm{~km})$ rifted continental crust at the southern terminus of the Terror Rift, a major graben located at the western margin of the West Antarctic rift system (Bannister et al., 2000; Cooper et al., 1987; Behrendt et al., 1991). About $4,520 \mathrm{~km}^{3}$ of volcanic material has been erupted on Ross Island over the last $\sim 4 \mathrm{Ma}$ (Esser et al., 2004).

The evolution of Erebus volcano has been established by ${ }^{40} \mathrm{Ar} /{ }^{39} \mathrm{Ar}$ age-dating (Esser et al., 2004; Harpel et al., 2004; Kelly et al., 2008). Development of the volcano can be divided into; (1) a proto-Erebus shield building phase (1.3 - 1.0 Ma); (2) a proto-Erebus cone building phase (1.0 Ma - $250 \mathrm{ka})$; and (3) the modern-Erebus cone building phase (250 ka - present). The first phase represents a transition from subaqueous to subaerial activity at $1.3 \mathrm{Ma}$, and is represented by eruption of basanite. During the second phase more evolved phonotephrite lavas formed steep summit slopes that were subsequently destroyed by a caldera collapse event at 
$\sim 750 \mathrm{ka}$ and followed by a period of flank eruptions. The bulk of the present-day Erebus edifice was formed during the third phase, when activity increased and large volumes of anorthoclasephyric tephriphonolite and phonolite lavas were extruded.

The present-day summit topography (Fig. 1) was formed by caldera collapse between 80 and 24 ka that created the summit plateau, and a second smaller nested caldera collapse that occurred between 25 and 11 ka (Harpel et al., 2004; Kelly et al., 2008). Post-collapse lava flows and pyroclastic deposits fill the calderas and form the summit cone, which consists of the larger Main Crater and adjacent inactive Side Crater.

All historic eruptive activity has originated from the lava lake and associated vents. The lava lake is located in the $\sim 160 \mathrm{~m}$ diameter, $\sim 100$-m-deep Inner Crater which is nested in the Main Crater (500 by $600 \mathrm{~m}$ diameter, $120 \mathrm{~m}$ deep). Lava bombs ejected from the lava lake are on average $30 \mathrm{~cm}$ to $2 \mathrm{~m}$ in diameter and typically land on the Main Crater floor and rim. In late 1984 the size and frequency of eruptions increased dramatically. Lava bombs up to $10 \mathrm{~m}$ in diameter were thrown up to $1 \mathrm{~km}$ above the Main Crater rim and over $1 \mathrm{~km}$ from the lava lake (Caldwell and Kyle, 1994). In early 1985 eruptive activity returned to normal and except for a quiescent period from mid-2003 to early 2004 has been sustained to the present (2007). Older bombs (pre-1972) are found up to $1.5 \mathrm{~km}$ from the Main Crater, indicating that activity like 1984 has occurred previously (Fig. 1). A lag gravel of anorthoclase crystals, formed by physical weathering of bombs, litter the summit cone. The bombs and crystals show that the activity observed over the last 35 years is not abnormal and has been sustained for several centuries or millennia (Kyle et al., 1982; Harpel et al., 2004).

\subsection{Petrology}


Alkaline, OIB-like basalts with low ${ }^{87 / 86} \mathrm{Sr}$ and HIMU enrichments are characteristic of Cenozoic West Antarctic rift volcanoes, although there is little agreement on their origin or significance here or in general (Finn et al., 2005; Panter et al., 2006). The basanite to phonolite lava suite found at Erebus volcano and termed the "Erebus Lineage" (EL), is alkaline and strongly Si-undersaturated (Kyle et al., 1992). EL lavas form continuous trends on major and trace element variation diagrams and have radiogenic ${ }^{206} \mathrm{~Pb} /{ }^{204} \mathrm{~Pb}$, unradiogenic ${ }^{87} \mathrm{Sr} /{ }^{86} \mathrm{Sr}$, and intermediate ${ }^{143} \mathrm{Nd} /{ }^{144} \mathrm{Nd}$ and ${ }^{176} \mathrm{Hf} /{ }^{177} \mathrm{Hf}$ (Kyle et al., 1992; Sims et al., 2008a). Based mainly on major and trace element data the EL lavas have been interpreted as a co-genetic sequence related by fractional crystallization (Kyle et al., 1992). New radiogenic isotope data suggest EL lavas are derived from a heterogeneous mantle source and undergo extensive mixing as well as fractional crystallization as they evolve from basanite to phonolite (Sims et al., 2008a).

Phonolite lavas have only been erupted recently in the history of Erebus volcano. A shift from tephriphonolite to phonolite occurred at $\sim 36 \mathrm{ka}$, after $1.3 \mathrm{Ma}$ of eruption of lessdifferentiated material (Harpel et al., 2004; Esser et al., 2004). The oldest phonolite lavas are found on the flanks of Erebus volcano (Esser et al., 2004).

\section{Sample descriptions, analytical methods, and results}

\subsection{Summit lavas}

Phonolite lavas from the summit region have an extreme phaneritic texture. Abundant $(\sim 30-40$ vol. \%) anorthoclase feldspar crystals up to $\sim 6 \mathrm{~cm}$ in length along with small amounts of olivine, opaque oxides, clinopyroxene, and apatite are found in a glassy groundmass that is black when fresh and weathers to lighter shades of gray. In hand specimen the individual summit lava flows are indistinguishable from each other. 
Major and trace element concentrations were determined for 11 whole rock samples from 10 dated lava flows from the summit plateau. The 11 lavas range in age from $17 \pm 8$ ka to $0 \pm 4$ ka (Harpel et al., 2004; Kelly et al., 2008). In order to minimize the effects of individual large anorthoclase phenocrysts on bulk composition, large $(1-5 \mathrm{~kg})$ lava samples were jaw crushed and ground into fine $(\sim 5-10 \mu \mathrm{m})$ powder with a tungsten carbide swing mill. Tantalum contamination was monitored using quartz "blanks." Major element concentrations were determined by XRF and trace elements by ICP-MS. Results, analytical details, and ages are summarized in Table 1.

For comparison to the older lavas, one previously unpublished whole rock analyses of a lava bomb erupted in 1997 (Eschenbacher, 1998) is included in Table 1.

\subsection{Lava bombs erupted from 1972 to 2004}

The 38 lava bombs examined here were erupted between December 1972 and January 2004 and collected from the Main Crater floor or around the crater rim. The exact time and date of eruption are known for some bomb samples and others were collected based on their fresh appearance. Recently erupted bombs have a distinctive metallic to iridescent vitreous luster that is quickly lost $(\sim 1-2$ weeks $)$ upon exposure to the acid gases continuously emitted from the lava lake and surrounding fumaroles. Based on their fresh condition, samples for which an exact date of eruption is unknown must have been erupted less than one month prior to collection.

Lava bomb textures are similar to the summit lavas. The main difference is that the quenched glassy matrix is much more bubble-rich, spindly, and fragile. Lava bombs feature the same mineral assemblage as the summit lavas: abundant ( $\sim 30$ vol. $\%)$ extremely large anorthoclase feldspar crystals up to $\sim 10 \mathrm{~cm}$ in length, small amounts of olivine, opaque oxides, 
clinopyroxene, and apatite in a glassy bubble-rich matrix. Twenty seven major element compositions and 27 trace element compositions of matrix glass from 38 lava bombs are summarized in Table 2. Major element concentrations were determined by electron microprobe and trace element concentrations by ICP-MS; analytical details are given with Table 2. Mineral compositions were determined by electron microprobe, and representative mineral analyses and analytical information are given in Tables 3 and 4.

\section{Whole rock geochemistry}

\subsection{Major and trace element concentrations of summit lavas}

All the lavas are Si-undersaturated phonolites that show strong enrichments in alkali and incompatible elements (Figs. 2 \& 3). The concentrations of some elements, such as $\mathrm{Mn}, \mathrm{Mg}, \mathrm{Ca}$, $\mathrm{Ti}, \mathrm{Cr}, \mathrm{P}$, and $\mathrm{V}$ are comparatively low due to extensive fractionation of clinopyroxene (52\%), olivine (16\%), Fe-Ti oxides (14\%) and apatite (3\%) during evolution from a parental basanite to phonolite (Kyle et al., 1992) (Table 2; Fig. 3). The rare earth elements (REE) are enriched, and light REE are strongly enriched with respect to the heavy REE $\left(\mathrm{La}_{\mathrm{N}} / \mathrm{Yb} \mathrm{b}_{\mathrm{N}}=24.1-25.3\right)$. The REE patterns of the lavas show slight relative depletions in the middle REE, which are consistent with fractional crystallization of clinopyroxene and apatite during evolution from basanite to phonolite (Fig. 3b).

Some major and all trace element concentrations in the lavas show variations outside of analytical error. $\mathrm{SiO}_{2}, \mathrm{Al}_{2} \mathrm{O}_{3}$, and $\mathrm{Na}_{2} \mathrm{O}$ vary little about their mean concentrations $(<3 \% ; 2 \sigma, \mathrm{n}$ $=11)$ whereas $\mathrm{CaO}$ and $\mathrm{K}_{2} \mathrm{O}$ show somewhat larger variations $(\sim 6 \% ; 2 \sigma)$. Most trace element concentrations vary by $20-25 \%(2 \sigma)$ about their mean values $(n=11)$. The largest absolute trace element variations are seen in elements that are either highly compatible or incompatible in 
anorthoclase feldspar. For example $\mathrm{Sr}$ varies from 726-1234 ppm and $\mathrm{Zr}$ varies from 799-1216 ppm (Table 1). Samples from the same lava flow (E87020 \& E87034) show compositional variations that are comparable to inter-flow variations (e.g. $\mathrm{Zr}=1084 \& 1216 \mathrm{ppm}$ ).

Strong correlations are observed between sets of elements that are either compatible or incompatible in anorthoclase feldspar (e.g. $\mathrm{CaO}$ vs. Sr, $\mathrm{r}^{2}=0.81$; $\mathrm{Sr}$ vs. $\mathrm{Ba}, \mathrm{r}^{2}=0.99 ; \mathrm{Zr}$ vs. Th, $\left.r^{2}=0.99\right)$. On the other hand, plots comparing anorthoclase-compatible and incompatible elements are anti-correlated (e.g. Ba vs. $\mathrm{Zr}, \mathrm{r}^{2}=0.51$; Fig. 4). The correlations do not follow fractional crystallization differentiation trends but define mixing lines that relate to the modal abundance of feldspar in each sample (Fig. 4). Larger modal abundance of feldspar will enrich a sample in feldspar-compatible elements (e.g. $\mathrm{SiO}_{2}, \mathrm{Al}_{2} \mathrm{O}_{3}, \mathrm{CaO}, \mathrm{Sr}, \mathrm{Ba}, \mathrm{Eu}$ ) while diluting incompatible elements, and vice versa. This is further illustrated by the REE plots where small Eu anomalies vary inversely with other REE concentrations (Fig. 3b). There are no temporal trends in the composition of lavas erupted in the last $\sim 17 \mathrm{ka}$.

\subsection{Incompatible element ratios}

Most incompatible element ratios (IERs) in the lavas are constant. For example, $\mathrm{Zr} / \mathrm{Rb}$, $\mathrm{Zr} / \mathrm{Th}, \mathrm{U} / \mathrm{Th}$, and $\mathrm{Nb} / \mathrm{Ta}$ show less variation than expected by analytical uncertainty $(<4.2 \%$; compound error). Some IERs are unaffected by anorthoclase content and can be used as a measure of differentiation. For example, $\mathrm{Lu}$ and $\mathrm{Hf}$ are strongly fractionated by apatite $\left(\mathrm{D}_{\mathrm{Lu}}=\right.$ 13.8-21.5, $\mathrm{D}_{\mathrm{Hf}}=0.730-0.878 ;$ Fujimaki, 1986) and Lu/Hf shows a progressive decreasing trend during magmatic evolution because the melt is saturated with respect to apatite, and apatite is removed (fractionated) at every stage of differentiation (Fig. 5). Within the 11 lava samples analyzed here $\mathrm{Lu} / \mathrm{Hf}$ varies by only $3.2 \%$ about the mean $(2 \sigma)$, indicating they have all reached 
the same degree of bulk differentiation. This reinforces the point that the observed compositional variations are controlled by the modal distribution of crystals within lava flows, and not differences in parental melt composition or other genetic processes.

\section{Mineralogy of lava bombs}

\subsection{Matrix glass}

Matrix glass was analyzed to determine if any compositional changes due to injection of less differentiated magma or fractional crystallization had occurred from $1972-2004$. Results are given in Table 2. Major element analyses of matrix glass by EMP show only analytical variability and the analyses are more a measure of analytical precision than compositional variations (Fig. 6). Trace element analyses of matrix glass separates show minor variations that are greater than expected by analytical uncertainty, which is typically less than $3 \%$. The variations are similar to those in the bulk lava analyses, where elements that are anorthoclasephyllic (e.g. Ba, Sr) show the greatest variability (Fig. 7). Replicate analyses show about as much variability as inter-sample comparisons and are best explained by a combination of analytical uncertainty and $0-3 \mathrm{wt} . \%$ contamination of glass separates with anorthoclase or small amounts of other minerals. If the variations reflected real changes in glass composition due to crystallization, a slightly different but measurable compositional trend would result from crystallization of the remainder of the mineral suite.

Matrix glass makes up $\sim 65$ to 75 wt. $\%$ of lava bombs and anorthoclase feldspar makes up $\sim 20$ to $30 \mathrm{wt} . \%$. Thus, the trace element concentrations of matrix glass separates mainly reflect the removal of feldspar. This is shown by an overall enrichment of most elements and strong 
depletions in $\mathrm{Ba}$, Sr, and Eu. (Fig. 3). Removal of apatite results in lower, very consistent $\mathrm{Lu} / \mathrm{Hf}$ $(0.0373 \pm 3.53 \%)$ (Fig. 5).

\subsection{Anorthoclase feldspar}

Anorthoclase feldspar phenocrysts up to $10 \mathrm{~cm}$ in length are the most striking feature of Erebus volcano lavas and lava bombs. Anorthoclase is also notable because it is the only mineral in recently erupted lava bombs that shows compositional zoning (Kyle, 1977; Caldwell and Kyle, 1994; Dunbar et al., 1994). Results of EMP traverses made on 8 crystals are summarized in Figure 8. The compositional profile of a rim-to-rim traverse across crystal 85010-01 is shown in Figure 9. The observed compositional range in the 8 crystals is $\mathrm{An}_{10.3-}$ ${ }_{22.9} \mathrm{Ab}_{62.8-68.1} \mathrm{Or}_{11.4-27.2}\left(\right.$ mean $\left.=\mathrm{An}_{16.2} \mathrm{Ab}_{65.8} \mathrm{Or}_{17.9} ; \mathrm{n}=755\right)$. An anorthoclase from lava 80020 (26 $\pm 4 \mathrm{ka}$; Esser et al., 2004) has a compositional range similar to modern anorthoclase $\left(\mathrm{An}_{10-}\right.$ ${ }_{18} \mathrm{Ab}_{65-68} \mathrm{Or}_{15-25} ; \mathrm{n}=5$; Moore, 1986).

A single ternary feldspar is found in all tephra. The crystallization path is around the nose of the solvus (Fig. 8), which is indicative of the high temperature and very low $\mathrm{H}_{2} \mathrm{O}$ activity in the Erebus magmatic system (Nekvasil, 1992). Compositional zoning in the anorthoclase is restricted to the An and Or components and the compositional range in each crystal is similar (Figs. 8, 9). Major-element variations are described below using only An because Or is its inverse and $\mathrm{Ab}$ varies little.

Two main types of compositional variation are observed in the crystals. Most of the compositional variance results from low-frequency sinusoidal to quasi-sinusoidal variations with periods of $\sim 3000$ to $5500 \mu \mathrm{m}$. The low-frequency variations have an amplitude of $\sim 2.5 \mathrm{~mol} \%$ An. The low-frequency variations feature the characteristics of type II zoning as described by 
Pearce (1994), except that the periods are larger. Low frequency variations within individual crystals are similar (Fig. 9). Superimposed upon the low-frequency variations are higher frequency variations with periods $<\sim 800 \mu \mathrm{m}$. The higher-frequency variations are typically $\leq 2$ mol \% An in amplitude. Some periodic behavior including normal and reverse asymmetric ("sawtooth") $300-500 \mu \mathrm{m}$ variations can be observed. These higher-frequency variations are similar to type I zoning described by Pearce (1994), but again with larger periods. The highfrequency variations cannot be correlated within individual crystals (Fig. 9) or between crystals erupted in the same bomb.

$\mathrm{BaO}, \mathrm{SrO}$, and $\mathrm{FeO}$ were measured in the anorthoclase by microprobe along with major elements (Fig. 9). Analytical precision prevents detailed interpretation of the profiles, but general comments on the trends are justified. $\mathrm{BaO}$ shows the most variability and is anticorrelated with An in most crystals. SrO is nearly constant and is decoupled from the major elements or may show weak positive correlation with $\mathrm{An}$. FeO is also nearly constant or shows some minor variability that is decoupled from the other elements. There are no systematic crystal-scale trends in the major or minor element profiles that suggest long-term changes in magma reservoir composition have occurred.

\subsection{Titanomagnetite}

Fe-Ti oxides re-equilibrate quickly (days to weeks) to changes in temperature and oxygen fugacity under magmatic conditions (Venezky and Rutherford, 1999) and their utility in elucidating fine-scale thermal magmatic processes has been demonstrated by many studies (e.g. Nakamura, 1995; Devine et al., 2003). Caldwell and Kyle (1994) explained small (2 mol \% ulvöspinel) variations in titanomagnetite compositions from Erebus lava bombs erupted between 
1972 and 1986 as due to a $10^{\circ}$ to $15^{\circ} \mathrm{C}$ progressive decrease in magmatic temperature. The result was based on a small number of analyses $(n=64)$ and the authors suggested a more comprehensive study was needed to confirm their findings.

We made 624 analyses on 216 individual crystals from 32 bombs erupted between 1972 and 2003 (a representative composition is given in Table 3) including the same samples analyzed by Caldwell and Kyle (1994), and could not replicate their results. Rather, our data show titanomagnetite composition was constant during this period. The variations reported by Caldwell and Kyle (1994) are likely to be analytical. Furthermore, 22 rim-to-rim electron microprobe traverses across crystals ranging in size from $25 \mu \mathrm{m}$ to $400 \mu \mathrm{m}$ show no statistically significant compositional differences. Titanomagnetite grains found in matrix glass are compositionally indistinguishable from titanomagnetite inclusions in olivine, pyroxene, and anorthoclase crystals. Small $(<20 \mu \mathrm{m})$ crystals are also compositionally indistinguishable from larger crystals.

Finally, titanomagnetite analyses from a $26 \pm 4$ ka old (Esser et al., 2004) phonolite lava (80020) (Moore, 1986) agree with analyses of titanomagnetite from modern bombs. Titanomagnetite with similar compositions have been erupted for at least $26 \pm 4 \mathrm{ka}$.

\subsection{Olivine}

Olivine in bombs erupted between 1979 and 2004 were analyzed and recalculated into three end members: fayalite $\left(\mathrm{Fa} ; \mathrm{Fe}_{2} \mathrm{SiO}_{4}\right)$, forsterite $\left(\mathrm{Fo} ; \mathrm{Mg}_{2} \mathrm{SiO}_{4}\right)$, and tephroite $\left(\mathrm{Te} ; \mathrm{Mn}_{2} \mathrm{SiO}_{4}\right)$ because of their high $\mathrm{MnO}$ content ( $2.5 \mathrm{wt} \%)$. A representative olivine composition is given in Table 3. The olivine composition range is $\mathrm{Fa}_{45.3-47.3} \mathrm{Fo}_{49.6-51.9} \mathrm{Te}_{2.8-3.2}$ with a mean composition of $\mathrm{Fa}_{46.3} \mathrm{Fo}_{50.7} \mathrm{Te}_{3.0}(\mathrm{n}=67)$. The observed compositional variations are within limits expected 
due to analytical uncertainty. The crystals show no chemical zoning or significant systematic compositional variations. Our measurements are identical to olivine analyses from tephra erupted between 1972 and 1986 (Caldwell and Kyle, 1994), a $26 \pm 4$ ka old (Esser et al., 2004) phonolite lava (80020) (Moore, 1987), and olivine included in anorthoclase phenocrysts from older ( 10's to 100's of years old) bombs scattered around the summit (Kyle, 1977). There has been no significant change in olivine composition for at least $26 \pm 4 \mathrm{ka}$.

\subsection{Clinopyroxene}

Clinopyroxene phenocrysts from bombs erupted in 1979 and 1992, and a phenocryst of unknown age occurring as a synneusis intergrowth with anorthoclase from the summit crystal lag were analyzed. A representative clinopyroxene composition is given in Table 3 . The range of compositions ( $\left.\mathrm{Wo}_{45.4-47.0} \mathrm{En}_{35.0-37.7} \mathrm{Fs}_{16.4-18.9}\right)$ is within expected analytical uncertainty. The mean composition $\left(\mathrm{Wo}_{46.1} \mathrm{En}_{36.6} \mathrm{Fs}_{17.3} ; \mathrm{n}=19\right)$ is similar to that obtained on a larger sample suite $\left(\mathrm{Wo}_{47} \mathrm{En}_{36} \mathrm{Fs}_{17} ; \mathrm{n}=47\right)\left(\right.$ Caldwell and Kyle, 1994). The lack of $\mathrm{Fe}^{3+}$ and $\mathrm{Na}$ variation in the pyroxene crystals suggests that oxygen fugacity is constant during clinopyroxene crystallization (Caldwell and Kyle, 1994). A clinopyroxene in a $73 \pm 10$ ka (Esser et al., 2004) tephriphonolite lava (E83448) (Kyle et al. 1992) is similar in composition $\left(\mathrm{Wo}_{45} \mathrm{En}_{38} \mathrm{Fs}_{17}\right)$ to those in the tephra.

\subsection{Fluor-apatite}

Microphenocrysts of fluor-apatite are common as hexagonal, acicular crystals in matrix glass and also as inclusions in olivine, clinopyroxene, titanomagnetite, and anorthoclase. Analysis of crystals in tephra erupted from 1979 to 2003 occurring in groundmass and as inclusions in minerals shows fluor-apatite composition to be constant within analytical limits. A 
representative fluor-apatite composition is given in Table 3. The fluor-apatites are notable for their high concentration of F $(\sim 3 \mathrm{wt} \%)$. Analyses of fluor-apatite from older lavas are not available.

\subsection{Pyrrhotite}

Small $(<50 \mu \mathrm{m})$ blebs of pyrrhotite, typically found contacting or within magnetite grains, are a very minor $(<1 \%$ mineral mode) though ubiquitous feature of tephra (Kyle, 1977). Pyrrhotite analyses from phonolite lava 80200 (26 \pm 4 ka; Esser et al., 2004) are indistinguishable from the analyses made on modern tephra. The compositions of pyrrhotite have been used to constrain the sulfur fugacity in the melt (Kyle, 1977).

\section{Intensive parameters and silica activity}

Several independent empirical and experimental approaches have demonstrated that a $\mathrm{T}$ of $1000^{\circ} \mathrm{C}$ is a reasonable magmatic temperature for the lava lake (optical pyrometer, mineral thermometer, Kyle, 1977; melt inclusion homogenization, Dunbar et al., 1994; olivine-cpx thermometry, Caldwell and Kyle, 1994; Forward Looking InfraRed (FLIR), Calkins et al., this volume). Using the olivine, titanomagnetite, and clinopyroxene data from Table 3, a temperature of $1000^{\circ} \mathrm{C}$ and pressure of 1 bar, the QUILF computer program (Anderson et al., 1993) returns a $\log \left(f \mathrm{O}_{2}\right)$ of $-11.86 \pm 0.03(\Delta \log \mathrm{FMQ}-0.88 \pm 0.03)$ (Fig. 10) and a silica activity $0.461 \pm 0.007$ for magma in the lava lake. The presence of pyrrhotite in the tephra is consistent with reducing conditions.

\section{Composition of the lava lake}




\section{Bulk composition from $\sim 17 \mathrm{ka}$ to present}

The bulk compositions of recently erupted lava bombs are indistinguishable from bulk compositions the older bulk phonolite lavas erupted in the last $\sim 17 \mathrm{ka}$. Bulk analyses of lava bombs erupted between 1972 and 1986 (Caldwell and Kyle, 1994) and an analysis of a bomb erupted in 1997 (Eschenbacher, 1998) show small compositional variations of the same magnitude and sense as the lavas that can be explained by variations in anorthoclase content (Table 5). Some bulk lava bomb analyses have slightly higher concentrations of incompatible oxides (e.g. $\mathrm{Na}_{2} \mathrm{O}$ ) and lower concentrations of compatible oxides (e.g. FeO) than lavas but the differences are too small and inconsistent to be considered significant. The data demonstrate that no significant change in bulk composition has occurred during this time.

Mineral modes of recently erupted lava bombs (Table 5) are similar to those of the summit lavas erupted over the last $\sim 17 \mathrm{ka}$ (Caldwell and Kyle, 1994). This implies that crystallization had proceeded to about the same point before eruption. Studies of other active steady state volcanoes have shown that nearly constant degrees of crystallization can be maintained over several decades (Landi et al., 2004; Streck et al., 2005), but our data suggest that Erebus has maintained a similar level of crystallization for thousands or tens of thousands of years.

\subsection{Composition of matrix glass from 1972 to 2004}

Matrix glass analyses show a very small compositional range and feature very consistent IERs. The consistency of IERs sensitive to differentiation demonstrate that no chemical changes due to crystallization or injection of other magma have occurred from 1972-2004 (Fig. 5). Therefore, crystallization is either progressing very slowly or perhaps not at all. If the system 
has reached a steady state, equal amounts of crystallization and dissolution could be occurring, yielding no net chemical change in the matrix glass chemistry.

Matrix glass in lava bombs is modern residual melt remaining from parental basanite. Mass balance models (Table 5) indicate that matrix glass is about a $68 \%$ residual melt of bulk phonolite or about a $16 \%$ residual melt fraction of basanite assumed to be parental to the EL (DVDP-105.53; Kyle et al., 1992). As an independent check, the residual melt fraction (F) can also be calculated if an element is assumed to be perfectly incompatible using the Rayleigh distillation equation (Wilson, 1989): $\mathrm{C}_{\mathrm{L}} / \mathrm{C}_{\mathrm{L}}^{0}=\mathrm{F}^{(\mathrm{D}-1)}$, where $\mathrm{C}_{\mathrm{L}}^{0}$ is the original concentration, $\mathrm{C}_{\mathrm{L}}$ is the final concentration, and $\mathrm{D}$ is the partition coefficient. $\mathrm{As} \mathrm{D} \rightarrow 0, \mathrm{C}_{\mathrm{L}} / \mathrm{C}_{\mathrm{L}}^{0}$ approaches $1 / \mathrm{F}$. Uranium in modern matrix glass $\left(\mathrm{C}_{\mathrm{L}}\right)$ is enriched by a factor of 7.6 over basanite taken to be parental for the EL $\left(\mathrm{C}_{\mathrm{L}}^{0}\right.$; sample DVDP-105.53; [U] = 1.2 ppm; Kyle et al., 1992), which yields a residual melt fraction of $13 \%$ and is in good agreement with the mass balance models.

\subsection{Long-term evolution and inferences on mantle source characteristics from evolved rocks}

Isotopic ratios $(\mathrm{Sr}, \mathrm{Nd}, \mathrm{Hf}, \mathrm{Pb})$ and trace element concentrations indicate Erebus lavas are derived from a HIMU-like mantle source at low degrees of partial melting (Sun and Hanson, 1976; Kyle et al., 1992; Sims et al., 2008a). While there is controversy over the use of IERs in ways similar to isotopic ratios (Halliday et al., 1995; Sims and DePaolo, 1997; Hofmann, 1997), selected IERs from the phonolite lavas support this conclusion. For example $\mathrm{Zr} / \mathrm{Rb}(10.2 \pm$ $2.4 \% ; 2 \sigma)$ and $\mathrm{Nb} / \mathrm{Ta}(17.3 \pm 2.2 \% ; 2 \sigma)$ are similar to average primitive OIB basalts $(\mathrm{Zr} / \mathrm{Rb}=$ 9.03, $\mathrm{Nb} / \mathrm{Ta}=17.8$; Sun and McDonough, 1989) and show little variation during differentiation

(Fig. 5). On the other hand, $\mathrm{Nb} / \mathrm{U}$ shows considerable variation during magmatic evolution (Fig. 5) and $\mathrm{Nb} / \mathrm{U}$ ratios in evolved rocks represent $\mathrm{FC}$ effects rather than source or melting 
characteristics. This highlights the fundamental tenet that magmatic evolution must be well understood before IERs are used to infer source characteristics, and that radiogenic isotopes are in general a more robust tool for investigating source and melting parameters (Sims and DePaolo, 1997). More importantly, such ideal "isotope-like" behavior of some IERs in the EL reflects the relative simplicity of magmatic evolution at Erebus and should be taken as an exception rather than a rule.

\section{Crystallization in the lava lake}

A silicate melt may become supersaturated and crystallize in response to cooling or if the concentration of one of its components changes. Both of these factors could impose some control on crystallization and crystal composition at Erebus volcano because magma simultaneously cools as well as degasses at and near the lava lake surface. Anorthoclase is the dominant precipitating phase ( $\sim 90 \mathrm{wt} . \%$ solid fraction; Table 5$)$ and textural relationships indicate that it is the last major mineral phase to crystallize. Compositional zoning and low volatile contents of melt inclusions in anorthoclase suggest that they form in a dynamic environment shallow in the system (i.e. < 400 m; Dunbar et al., 1994; Eschenbacher, 1998; Seaman et al., 2006).

In the following discussion we conceptually take into account the effects cooling can have on crystallization and crystal composition versus changes in $P_{\mathrm{H} 2 \mathrm{O}}$ due to shallow degassing. Changes in pressure $(\mathrm{P})$ are not considered because $\mathrm{P}$ exerts small control on the composition of feldspar and the anorthoclase likely experience a limited $\mathrm{P}$ range ( $<100 \mathrm{MPa})$. Strict changes in $\mathrm{P}$ are not likely to influence the composition of the anorthoclase inasmuch as intensive properties and $P_{\mathrm{H} 2 \mathrm{O}}$ vary with depth in the conduit. 


\subsection{Cooling-induced crystallization}

Magma that forms the crust of the lava lake is quickly cooled from $\sim 1000^{\circ} \mathrm{C}$ to 500 $600^{\circ} \mathrm{C}$ (Calkins et al., 2007) before it is recycled back into the magma conduit and assimilated back into the melt. However these large $\mathrm{T}$ changes are not reflected in titanomagnetite compositions, which are constant. This is probably because at lower pressure magnetite crystals take longer to reequilibrate to new T conditions (i.e. several weeks; Venezky and Rutherford, 1999), and cooled crust is rarely at the surface of the lava lake for more than $10-20$ minutes before it sinks back into the conduit and presumably assimilated back into the magma chamber. Beneath the relatively thin crust $(\sim 1 \mathrm{~m})$, magma cools little and is $\sim 950-1000^{\circ} \mathrm{C}$ (Calkins et al., 2007). Therefore, if cooling drives crystallization it would most likely occur as the cold degassed slab sinks into the conduit and is reheated.

The effects of $\mathrm{T}$ on feldspar compositions are relatively well understood (e.g. Johannes, 1978; Loomis and Welber, 1982; Housh and Luhr, 1991) and experiments on plagioclase indicate that the slope of the solidus is around $1 \mathrm{~mol} . \% \mathrm{An} / 5^{\circ} \mathrm{C}$ for intermediate compositions (Housh and Luhr, 1991). Assuming anorthoclase behave in roughly the same manner as plagioclase, we would expect large An variations in the anorthoclase because the temperature variations involved are very large. This is not the case; the total range of An variation observed is only $13 \mathrm{~mol} . \%$. Furthermore, if supercooling and large T variations were controlling crystallization, kinetic effects would influence crystal and MI compositions (Kirkpatrick, 1981; Cashman, 1990) because at such extreme degrees of undercooling melt viscosity would increase dramatically and replenishment of elements to the crystal $/$ melt interface would be impeded. High crystal growth rates would further compound the effect and lead to the formation of a 
compositional boundary layer around the crystals (Marsh, 1989). Boundary layers are not observed in quenched samples and the compositions of melt inclusions trapped during crystal growth show very small variations when compared to matrix glass (Kyle, 1977; Dunbar et al., 1994). This indicates that crystal growth rates are either less than or about equal to elemental diffusion rates in the melt, which implies large degrees of undercooling are not driving crystal growth.

Finally, at undercoolings on the order of $500^{\circ} \mathrm{C}$ the solvus would be intersected and a two-feldspar assemblage would precipitate. Rare sanidine overgrowths and microlites are found in older lavas from the flanks of Erebus (Moore, 1986; Kyle et al., 1992) but these probably formed as the lavas cooled after eruption. Quenched lava bombs provide no evidence that a twofeldspar assemblage has ever precipitated in the magma chamber. Therefore, while cooling is undisputedly occurring at the surface of the lava lake, it is not considered an important control on crystallization and hence crystal composition.

\subsection{Decompression-induced crystallization}

Water is very soluble in silicate melts, but ascent and decompression to low pressure will cause water to saturate and exsolve. It has become recognized that syn-eruptive degassing and crystallization is a common phenomenon in shallow volcanic systems that can have important implications for eruption dynamics (e.g. Klug and Cashman, 1994; Hammer et al., 1999; Cashman and Blundy, 2000). Furthermore, experimental studies (Geschwind and Rutherford, 1995; Hammer and Rutherford, 2002; Couch, 2003; Couch et al., 2003a,b) have demonstrated that information about the magnitude and history of decompression can be recorded in groundmass textures. 
Exsolution of water raises the liquidus temperature and can drive groundmass microlite crystallization (Tuttle and Bowen, 1958; Geschwind and Rutherford, 1995; Metrich and Rutherford, 1998; Hammer et al., 1999; Cashman and Blundy, 2000; Hammer et al., 2000). The difference between the magmatic temperature and the (new) liquidus temperature that results from degassing is called the effective undercooling $\left(\Delta \mathrm{T}_{\text {eff }}\right)$. Since the change in the liquidus drives crystallization there need be no actual change in temperature for crystallization to proceed. Indeed, the latent heat of crystallization can balance the heat lost from volatile exsolution and the entire process can be nearly isothermal (Métrich and Rutherford, 1998; Couch et al., 2003a), or may lead to magma heating (Blundy et al., 2006). Experimental studies have shown that high degrees of $\Delta \mathrm{T}_{\text {eff }}$ lead to large numbers of microlite nucleation per unit area $\left(\mathrm{N}_{\mathrm{A}}\right)$ and result in dense populations of small crystals (Hammer and Rutherford, 2002; Couch, 2003; Couch et al., 2003a; b; Larsen, 2005). Conversely, lower degrees of $\Delta \mathrm{T}_{\text {eff }}$ results in low $\mathrm{N}_{\mathrm{A}}$ and fewer numbers of larger crystals. These two extremes are referred to as "nucleation dominated" and "growth dominated" regimes. In both cases the total mass crystallized can be similar, but in nucleation dominated cases the mass is spread over many sites growing at a slow rate and in growth dominated cases the mass is crystallized on few sites at a faster rate (Larsen, 2005).

\subsection{Controls on crystallization in the lava lake}

The textures and mineralogic compositions of recently erupted lava bombs are consistent with crystallization at low degrees of undercooling in a growth-dominated regime. Textural evidence includes crystal size distributions that show nucleation sites are extremely scarce $\left(\mathrm{N}_{\mathrm{A}} \approx\right.$ 0 ), the very large size of anorthoclase (up to $10 \mathrm{~cm}$ ), and that matrix glass is essentially microlite free (Dunbar et al., 1994). Nucleation sites are so scarce that titanomagnetite, olivine, 
clinopyroxene, and apatite crystals are commonly found as inclusions in anorthoclase and may serve as nucleation sites for some anorthoclase crystals.

The small compositional range of the anorthoclase and homogeneous compositions of other minerals are also consistent with fairly subtle changes in conditions driving crystallization. The effect of cooling on anorthoclase chemistry has not been investigated experimentally, but assuming a change of $1 \mathrm{~mol} . \%$ An per $5^{\circ} \mathrm{C}$ means typical high frequency variations could be caused by about $10^{\circ} \mathrm{C}$ of undercooling and the entire range of compositions ( $13 \mathrm{~mol} . \%$ An) by about $65^{\circ} \mathrm{C}$ of undercooling. Small transient changes in $\mathrm{T}\left(\right.$ i.e. $\sim 10^{\circ} \mathrm{C}$ ) could occur without significantly affecting titanomagnetite compositions, but it seems unlikely that sustained larger temperature variations necessary to explain the full range of anorthoclase compositions could occur without affecting titanomagnetite. On the other hand, measured water contents of melt inclusions in anorthoclase show small variations (0.12 to 0.39 wt.\%; Seaman et al., 2006) and offer evidence that $\mathrm{P}_{\mathrm{H} 2 \mathrm{O}}$ varies within the conduit while anorthoclase are crystallizing. Therefore it seems more likely that changes in $\mathrm{P}_{\mathrm{H} 2 \mathrm{O}}$ and $\Delta \mathrm{T}_{\text {eff }}$ are the principle controls on crystallization and crystal composition. We cannot rule out small changes in temperature and/or crystal growth kinetics having some control on compositional zoning, but these are likely reflected in the smaller high frequency variations while changes in $\mathrm{P}_{\mathrm{H} 2 \mathrm{O}}$ drive crystallization and are recorded in the low frequency variations.

Unlike microlites that form during a single episode of ascent and eruption, there is abundant textural and chemical evidence to suggest that Erebus anorthoclase experience multiple episodes of decompression and rim growth (Dunbar et al., 1994). Therefore a likely scenario is that shallow convection in the lava lake promotes the growth of large crystals (Dunbar et al., 1994). Ostwald ripening (e.g. Higgins, 1998), where small crystals dissolve and transfer their 
mass to larger ones, is sometimes invoked to explain the presence of very large crystals but continuous crystal size distributions (Dunbar et al., 1994) argue against this being an important process in the lava lake.

In summary, a model of anorthoclase crystallization driven mainly by shallow exsolution of water is preferred over a cooling model. Decompression-induced crystallization is in greater accord with the homogeneous titanomagnetite compositions, the relatively subtle compositional zoning in the anorthoclase, and the microlite free matrix glass texture. We propose that shallow water exsolution causes crystallization to occur in the growth-dominated regime and shallow convection repeats this process multiple times, yielding the extremely large anorthoclase crystals. Clearly, experiments on anorthoclase from Erebus volcano would allow much better constraints to be placed on the conditions and processes governing crystal growth and should be a priority for future investigations.

\section{Comparison with other persistently active volcanoes}

Persistently active volcanoes are rare, and only a few have active lava lakes like Erebus. Persistently active volcanoes with petrologically well-studied eruption products include Stromboli, Italy (e.g. Francalanci et al., 1999, 2004; Cortés et al., 2005), Kilauea, Hawai'i (e.g. Garcia et al., 2003), and Arenal, Costa Rica (e.g. Reagan et al., 1986; Streck et al., 2005). Lava lakes have been observed at Kilauea over the last 200 years (e.g Tilling, 1987; Garcia et al., 2003) and other volcanoes with active lava lakes include Erta 'Ale, Ethiopia (e.g. Le Guern et al., 1979; Oppenheimer et al., 2004), Nyiragongo, Democratic Republic of Congo (e.g. Tazieff, 1984), Masaya, Nicaragua (e.g. Stoiber et al., 1986) and Villarrica, Chile (Witter et al., 2004). 
Major and trace element compositions of ejecta from Stromboli and Kilauea have shown small variations in the last $100-200$ years (Francalanci et al., 2004; Garcia et al., 2003), and much larger changes have occurred at Stromboli in the last $26 \mathrm{ka}$ (Cortés et al., 2005). In both cases, multiple magma compositions, mixing, and complex crystallization and differentiation histories have been invoked to explain small observed short (days) and long-term (ky's) compositional variations. Temporal chemical changes at volcanoes have been exploited to infer important parameters like residence time (Albarède, 1993) and mixing rates (Reagan et al., 1986), but at Erebus these approaches fail due to the extreme homogeneity of its lava and tephra. Eruption products from these classic persistently active volcanoes show greater bulk chemical, mineralogical, and isotopic variability than lavas and tephra erupted from Erebus volcano in the last $\sim 17 \mathrm{ka}$.

Arenal volcano has been erupting since 1968 with very little bulk compositional variation since 1970 (Streck et al., 2005). A detailed mineralogic study of the seemingly "monotonous" lavas erupted since 1970 reveal a complex and diverse growth and mixing histories of the crystal assemblage. This contrasts with the mineral assemblage found in lavas and tephra from Erebus which have not changed in composition for at least $\sim 26 \mathrm{ka}$. The extreme homogeneity of the crystals, lack of disequilibrium features, and MI and preliminary oxygen isotope data indicate that the minerals found in lavas and tephra grew from magma with the composition of bulk phonolite (Kyle, 1977; Dunbar et al., 1994; Kelly, 2006). Unlike samples from Arenal, there is no evidence to suggest the crystals are xenocrystic in origin. Thus the differentiation process that creates the bulk phonolite composition at Erebus is older than the crystals found in the lavas and tephra. 
It has been proposed that activity at persistently active volcanoes like Kilauea, Stromboli, and Arenal is sustained by a constant supply of fresh mantle-derived magma to upper levels of the volcanic system (e.g. Francis et al., 1993; Garcia et al., 2003; Francalanci et al., 2004; Streck et al., 2005). There is no evidence to suggest this is the case at Erebus volcano. While the lava lake has been constantly degassing, the net exogenous growth from 1972 to the present has been effectively zero, and campaign GPS surveys over the last five years show little or no evidence for endogenous growth of the volcanic edifice due to magma injection. Instead, observations over the last $30+$ years indicate that lava lake activity at Mt. Erebus is sustained by convective exchange of magma from a deeper reservoir to the surface via an open conduit (e.g. Stevenson and Blake, 1998; Harris et al., 1999). Lava lakes at Erta 'Ale (Oppenheimer et al., 2004) and Villarrica (Witter et al., 2004) are thought to be sustained in the same way.

While it appears that the upper level magmatic system at Erebus volcano is closed to continuous input of new magma, gas flux measurements, melt inclusion, and preliminary oxygen isotope data (Kelly, 2006) suggest that volatiles are added to the upper level magma chamber from deeper in the system (Eschenbacher, 1998; Wardell et al., 2004), possibly on a continuous basis. Decoupled movement of volatiles and magma has been inferred to occur at many volcanoes (e.g. Stromboli, Allard et al., 1994; Mount Etna, D'Alessandro et al., 1997). If this is the case at Erebus, variations in the flux of volatiles from deep in the system may play a role in driving eruptive activity. It follows that the heightened eruptive activity observed in late-1984 could have been triggered by an episodic addition of a large amount of volatiles without concomitant addition of magma. On the other hand, it has also been proposed that physical changes in the conduit are responsible for the formation of the large gas slugs that result in Strombolian eruptions (Aster et al., 2003; Grêt et al., 2005). Both processes may be important, 
and ongoing integrated gas monitoring and geophysical studies (Aster et al., 2004) should help elucidate what is driving activity at Erebus volcano.

\section{Conclusions}

(1) Major and trace element analyses of summit lavas and modern bombs reveal that the bulk composition of material erupted from Erebus volcano has remained nearly constant for $\sim 17 \mathrm{ka}$. Small bulk compositional variations result from differences in modal proportions of anorthoclase feldspar in the samples, although it is unclear if this is a result of pre-, syn-, or post-eruptive processes.

(2) The compositions of matrix glasses from lava bombs erupted in the last 31 years indicate that no measurable crystallization, assimilation, or mixing with magma of different composition has occurred during this time. Crystallization may be progressing slowly or not at all, and the homogeneity of the mineral assemblage indicates that the system is at or close to equilibrium. Eruptive activity is decoupled from magma composition and is more likely controlled by conduit geometry and/or the flux of volatiles from deeper in the system.

(3) Titanomagnetite compositions in lava bombs erupted between 1972 and 2003 are constant. This conclusion differs from Caldwell and Kyle (1994), who interpreted small ( $2 \mathrm{~mol} \%$ ulvöspinel) compositional variations in titanomagnetite as due to a progressive $10^{\circ}$ to $15^{\circ} \mathrm{C}$ decrease in magmatic temperature from 1972 to 1986 . Rather, our data show that magmatic temperature has been stable from 1972 to 2003 . The variation interpreted by Caldwell and Kyle (1994) was smaller than the analytical resolution of their data. 
(4) Lava bomb textures and mineralogical compositions are consistent with a model where crystallization and crystal compositions are largely controlled by shallow degassing of water. We propose that water exsolution causes crystallization to occur in the growthdominated regime and shallow convection repeats this process multiple times, yielding the extremely large anorthoclase crystals. Experiments on anorthoclase from Erebus volcano would allow much better constraints to be placed on the conditions and processes governing crystal growth and should be a priority for future investigations.

(5) Mineralogical data indicate the mineral assemblage found in lavas and bombs crystallizes in the lava lake/upper level magma chamber from melt with the composition of bulk phonolite. There is no evidence to suggest the crystals found in the summit lavas or recently erupted lava bombs are xenocrysts. Thus, the differentiation processes that create bulk phonolite melt are older than the crystals found in the bombs. The style and nature of magma replenishment to the upper level system is not known, but if the 10 summit lava flows are assumed to have erupted in response to individual recharge events the recurrence interval is $\sim 1.1$ to $2.5 \mathrm{ka}$.

(6) The large size of Erebus volcano, its persistent activity, and the constant composition of material erupted over the past $\sim 17 \mathrm{ka}$ are broadly consistent with the Erebus magmatic system being very large and very stable. However, the residence time of magma, the volume of the upper level magma chamber, and the chamber's location in the crust are very poorly constrained at present. Placing better estimates on these fundamental properties should be the focus of future research.

(7) Open-conduit conditions efficiently degas magma in the upper-level chamber, but if circumstances changed to allow accumulation of volatiles, the potential for explosive 
activity at Erebus volcano is great. Tephra layers found up to $\sim 180 \mathrm{~km}$ away indicate that explosive activity has occurred at Erebus volcano throughout the Pleistocene and Holocene (Harpel et al., 2004), probably because of volatile build-up. The governing factors that lead to open or closed conduit conditions are hereto unknown.

\section{Acknowledgments}

The work at Erebus volcano and the continued operation of the Mount Erebus Volcano Observatory is supported by grants (OPP-0229305, ANT-0538414) from the Office of Polar Programs, National Science Foundation. We thank Dr. Tom Wagner for his encouragement and continued support. Field work at Erebus is difficult at the best of times but possible because of wonderful support from past and present NSF-directed civilian contractors Antarctic Support Associates and Raytheon Polar Services Company. Special thanks go to the helicopter crews from PHI and Helicopters New Zealand; they are our lifeline in many ways. Many people have been involved in the field operations and thanks go to them all. Thanks to Lynn Heizler for help with the electron microprobe analyses. We appreciate the assistance of Terry Plank and colleagues at Boston University for the ICP-MS trace element analyses. PJK thanks Ryan Jakubowski, Garrett Kramer, Bill McIntosh, Shauna Mikelich, Robert Wyckoff, and Sylvain Pichat for keen repartee and encouragement pertaining to this work. We thank Alain Burgisser and an anonymous reviewer for constructive comments that improve the manuscript. 


\section{References}

Albarède, F., 1993. Residence time analysis of geochemical fluctuations in volcanic series. Geochim. Cosmochim. Acta. 57, 615-621.

Allard, P., Carbonnelle, J., Metrich, N., Loyer, H., Zetttwoog, P., 1994. Sulfur output and magma degassing budget of Stromboli volcano. Nature 368, 326-330.

Anderson, D. J., Lindsley, D.H., 1988. Internally consistent solution models for FeMg-Mn-ti oxides: Fe-Ti oxides. American Mineralogist 73, 714-726.

Andersen D. J., Lindsley D. H., Davidson P. M., 1993. QUILF: A Pascal program to assess equilibria among Fe-Mg-Mn-Ti oxides, pyroxenes, olivine, and quartz. Comp. Geosc. 19, 1333-1350.

Aster, R., Mah, S.Y., Kyle, P., McIntosh, W., Dunbar, N., Johnson, J., Ruiz, M., McNamara, S., 2003. Very long period oscillations of Mount Erebus volcano, J. Geophys. Res., 108 (B11), 2522, doi:10.1029/2002JB002101.

Aster, R., McIntosh, W., Kyle, P., Esser, R., Bartel, B., Dunbar, N., Johns, B., Johnson, J., Karstens, R., Kurnik, C., McGowan, M., McNamara, S., Meertens, C., Pauly, B., Richmond, M., Ruiz, M., 2004. New instrumentation delivers multidisciplinary real-time data from Mount Erebus, Antarctica. EOS trans. AGU., 85, no. 10, 9 March.

Bannister, S., Snieder, R.K., Passier, M.L., 2000. Shear-wave velocities under the Transantarctic Mountains and Terror Rift from surface wave inversion, Geophys. Res. Lett. 27, 281284.

Behrendt, J.C., LeMasurier, W.E., Cooper, A.K., Tessensohn, F., Trehu, A., Damaske, D., 1991. Geophysical studies of the West Antarctic rift system. Tectonics 10, 1257-1273.

Blundy, J., Cashman, K., Humphreys, M., 2006. Magma heating by decompression-driven crystallization beneath andesite volcanoes. Nature. 443, 76-80.

Caldwell, D., Kyle, P.R., 1994. Mineralogy and geochemistry of ejecta erupted from Mount Erebus, Antarctica between 1972 and 1986, In: Kyle, P.R. (ed) Volcanological and Environmental Studies of Mount Erebus, Antarctica, Antarct. Res. Ser., vol. 66, Am Geophys Union, Washington, D.C. 147-162.

Calkins, J., Oppenheimer, C., Kyle, P.R., 2007. Ground-based thermal imaging of lava lakes at Mount Erebus Volcano, Antarctica in December 2004. J. Volcanol. Geotherm. Res. (this volume). 
Cashman, K.V., 1990. Textural constraints on the kinetics of crystallization of igneous rocks. In: Nicholls, J., Russell, J.K. (eds) Reviews in mineralogy, vol. 24. Modern methods of igneous petrology, understanding magmatic processes. Mineral. Soc. Am., Washington, D.C. 259-314.

Cashman, K.V., Blundy, J., 2000. Degassing and crystallization of ascending andesite and dacite. Philos. Trans. R. Soc. London. Ser. A, 358, 1487-1513.

Cooper A.K., Davey F.J., Behrendt J.C., 1987. Seismic stratigraphy and structure of the Victoria Land basin, western Ross Sea, Antarctica. in: Cooper A.K., Davey F.J. (eds) The Antarctic Continental Margin: geology and geophysics of the western Ross Sea. Circum-Pacific Council for Energy and Resources, Houston, 27-65.

Cortés, J.A., Wilson, M., Condliffe, E., Francalanci, L., Chertkoff, D. G., 2005. The evolution of the magmatic system of Stromboli Volcano during the Vancori period (26-13.8 ky). J. Volcanol. Geotherm. Res. 147, 1-38.

Couch, S., 2003. Experimental investigation of crystallization kinetics in a haplogranite system. American Mineralogist. 88, 1471-1485.

Couch, S., Harford, C.L., Sparks, R.S.J., and Carroll, M.R., 2003a. Experimental constraints on andesite petrogenesis at the Soufrière Hills Volcano, Montserrat. Journal of Petrology. 44, 1455-1475.

Couch, S., Sparks, R.S.J., and Carroll, M.R., 2003b. The kinetics of degassing induced crystallization at Soufrière Hills Volcano, Montserrat. Journal of Petrology. 44, 1477-1502.

D'Alessandro, Giammanco, S., Parello, F., Valenza, 1997. $\mathrm{CO}_{2}$ output and $\delta^{13} \mathrm{C}\left(\mathrm{CO}_{2}\right)$ from Mount Etna as indicators of degassing of shallow asthenosphere. Bull. Volcanol. 58, 455-458.

Devine, J.D., Rutherford, M.J., Norton, G.E., Young, S.R., 2003. Magma storage region processes inferred from geochemistry of Fe-Ti oxides in andesitic magma, Soufrière Hills Volcano, Montserrat, W.I. Journal of Petrology. 44, 1375-1400.

Dunbar, N., Cashman, K., Dupre, R., 1994. Crystallization processes of anorthoclase phenocrysts in the Mount Erebus magmatic system: Evidence from crystal composition, crystal size distributions and volatile contents of melt inclusions. In: Kyle, P.R. (ed.) Volcanological and Environmental Studies of Mount Erebus, Antarctica, Antarct. Res. Ser., 66, AGU, Washington, D. C. 129-146. 
Elkins, L.T., Grove, T.L., 1990. Ternary feldspar experiments and thermodynamic models. American Mineralogist. 75, 544-559.

Eschenbacher, A. 1998. Open-system degassing of a fractionating, alkaline magma, Mount Erebus, Ross Island, Antarctica. Unpublished Master's Thesis, New Mexico Institute of Mining and Technology, Socorro.

Esser R.P., Kyle P.R., McIntosh W.C., 2004. ${ }^{40} \mathrm{Ar}{ }^{39}$ Ar dating of the eruptive history of Mount Erebus, Antarctica: Volcano evolution. Bull. Volcanol. 66, 671-686.

Finn, C.A., Müller, R.D., Panter, K.S., 2005. A Cenozoic diffuse alkaline magmatic province (DAMP) in the southwest Pacific without rift or plume origin. Geochemistry Geophysics Geosystems. 6, Q02005, doi:10.1029/2004GC000723.

Francalanci, L., Tommasini, S., Conticelli, S., Davies, G. R., 1999. Sr isotope evidence for short magma residence time for the $20^{\text {th }}$ century activity at Stromboli volcano, Italy. Earth. Planet. Sci. Lett. 167, 61-69.

Francalanci, L., Tommasini, S., Conticelli, S., 2004. The volcanic activity of Stromboli in the 1906-1998 AD period: mineralogical, geochemical and isotope data relevant to the understanding of the plumbing system. J. Volcanol. Geotherm. Res. 131, 179-211.

Francis, P., Oppenheimer, C., Stevenson, D., 1993. Endogenous growth of persistently active volcanoes. Nature. 366, 554-557.

Frost, R.B., Lindsley, D.H., Anderson, D.J., 1988. Fe-Ti oxide-silicate equilibria: Assemblages with fayalitic olivine. American Mineralogist, 73, 727-740.

Fujimaki, H., 1986. Partition coefficients of Hf, Zr, and REE between zircon, apatite, and liquid. Contrib. Min. Petrol. 94, 42-45.

Garcia, M.O., Pietruszka, A.J., Rhodes, J. M., 2003. A petrologic perspective of Kilauea Volcano's summit magma reservoir. Journal of Petrology. 44, $2313-$ 2339.

Geschwind, C., Rutherford, M.J., 1995. Crystallization of microlites during magma ascent; the fluid mechanics of 1980-1986 eruptions at Mount St. Helens. Bull. Volcanol. 57, 356-370.

Giggenbach, W., Kyle, P., Lyon, G., 1973. Present volcanic activity on Mt. Erebus, Ross Island, Antarctica. Geology. 1, 135- 156.

Goff, F., Love, S., Warren, R., Counce, d., Obenholzner, J., Seibe, C., and Schmidt, S., 2001. Passive infrared remote sensing evidence for large, intermittent $\mathrm{CO}_{2}$ emissions at Popocatepetl volcano, Mexico. Chemical Geology. 177, 133-156. 
Grêt, A., Snieder, R., Aster, R.C., Kyle, P.R., 2005. Monitoring rapid temporal change in a volcano with coda wave interferometry. Geophys Res Lett. 32, L06304, doi:10.1029/2004GL021143.

Hallett, R.B., Kyle, P.R., 1993. XRF and INAA determinations of major and trace elements in Geological Survey of Japan igneous and sedimentary rock standards. Geostandards Newsletter. 17, 127-133.

Halliday, A.N., Lee, D.-c., Tommasini, S., Davies, G.R., Paslick, C.R., Fitton, J.G., James, D.E. 1995. Incompatable trace elements in OIB and MORB and source enrichment in the sub-oceanic mantle. Earth. Plan. Sci, Lett. 133, 379-395.

Hammer, J.E., Cashman, K.V., Hoblitt, R.P., Newman, S., 1999. Degassing and microlite crystallization during pre-climatic events of the 1991 eruption of Mt. Pinitubo, Philippines. Bull. Volcanol. 60, 355-380.

Hammer, J.E., Cashman, K.V., Voight, B., 2000. Magmatic processes revealed by textural and compositional trends in Merapi dome lavas. J. Volcanol. Geotherm. Res. 100, 165-192.

Hammer, J.E., Rutherford, M.J., 2002. An experimental study of the kinetics of decompression-induced crystallization in silicic melt. J. Geophys. Res., DOI: 10.1029/2001JB000281.

Harpel, C.J., Kyle P.R., Caldwell, D.A., McIntosh W.C., Esser R.P., 2004. ${ }^{40} \mathrm{Ar} /{ }^{39} \mathrm{Ar}$ dating of the eruptive history of Mount Erebus, Antarctica: summit flows and caldera collapse. Bull. Volcanol. 66, 687-702.

Harris, A.J.L., Flynn, L.P., Rothery, D.A., Oppenheimer, C., Sherman, S.B., 1999. Mass flux measurements at active lava lakes: Implications for magma recycling. J. Geophys. Res. 104, 7117-7136.

Higgins, M., 1998. Origin of anorthosite by textural coarsening: Quantitative measurements of a natural sequence of textural development. Journal of Petrology. 39, 1307-1323.

Hofmann, A.W., 1997. Mantle geochemistry: the message from oceanic volcanism. Nature. 385, 219-229.

Housh, T.B., Luhr, J.F., 1991. Plagioclase - melt equilibria in hydrous systems. American Mineralogist. 76, 477-492

Johannes, W., 1978. Melting of plagioclase in the system $\mathrm{Ab}-\mathrm{An}-\mathrm{H}_{2} \mathrm{O}$ at $\mathrm{P}_{\mathrm{H} 2 \mathrm{O}} \leq 5$ kbars, an equilibrium problem. Contrib. Miner. Petrol. 66, 295-303. 
Kelly, P., 2006. Geochemistry and mineralogy of the phonolite lava lake, Mount Erebus volcano, Antarctica: 1972 to 2004 and comparison with older lavas. Unpublished Master's Thesis, New Mexico Institute of Mining and Technology, Socorro, U.S.A.

Kelly, P.J., Dunbar, N.W., Kyle, P.R., McIntosh, W.C., 2008. Refinement of the younger geologic history of Erebus volcano, Antarctica using ${ }^{40} \mathrm{Ar} /{ }^{39} \mathrm{Ar}$ and ${ }^{36} \mathrm{Cl}$ age determinations. J. Volcanol. Geotherm. Res. (this issue).

Kelley, K.A., Plank, T., Ludden, J., Staudigel, H., 2003. Composition of altered oceanic crust at ODP sites 801 and 1149. Geochemistry, Geophysics, Geosystems 4 (6). Doi:10.1029/2002GC000435.

Kirkpatrick, R.J., 1981. Kinetics of crystallization of igneous rocks. In: Lasaga, A.C., Kirkpatrick, R.J. (eds), Kinetics of geological processes. Reviews in mineralogy, 8. Mineral. Soc. Am., Washington, D.C. 321-398.

Klug, C., Cashman, K.V., 1994. Vesiculation of May 18, 1980, Mount St. Helens magma. Geology. 22, 468-472.

Kyle P.R., 1977. Mineralogy and glass chemistry of recent volcanic ejecta from Mt. Erebus, Ross Island, Antarctica. NZ J Geol Geophys. 20, 1123-1146.

Kyle, P., 1986. Volcanic activity of Mount Erebus, 1984 - 1986, Antarct. J. U.S., XXI, 7-8.

Kyle, P.R., 1990a. McMurdo Volcanic Group-Western Ross Embayment: introduction. in: LeMasurier, W., Thomson, J. (eds) Volcanoes of the Antarctic Plate and Southern Oceans. Antarctic Research Series. Am Geophys Union, Washington, DC. 18-25.

Kyle, P.R., 1990b. Erebus Volcanic Province. in: LeMasurier, W., Thomson, J. (eds) Volcanoes of the Antarctic Plate and Southern Oceans. Antarctic Research Series. Am Geophys Union, Washington, DC

Kyle P.R., Cole, J.W., 1974. Structural control of volcanism in the McMurdo Volcanic Group, Antarctica. Bull Volcanol. 38, 16-25.

Kyle, P., Dibble, R., Giggenbach, W., Keys, J., 1982. Volcanic activity associated with the anorthoclase phonolite lava lake, Mt. Erebus, Antarctica, in: C. Craddock (ed), Antarctic Geosciences, Univ. Wisc. Press, Madison, 735-745.

Kyle P.R., Moore J.A., Thirlwall M.F., 1992. Petrologic evolution of anorthoclase phonolite lavas at Mount Erebus, Ross Island, Antarctica. J. Petrol. 33, 849875. 
Landi, P., Metrich, N., Bertagnini, A., Rosi, M., 2004. Dynamics of magma mixing and degassing recorded in plagioclase at Stromboli (Aeolian Archipelago, Italy). Contrib. Min. Petrol. 147, 213-227.

Larsen, J.F., 2005. Experimental study of plagioclase rim growth around anorthite seed crystals in rhyodacitic melt. American Mineralogist. 90, 417-427.

LeBas, M.J., LeMaitre, R.W., Streckeisen, A., and Zanettin, B., 1986. A chemical classification of volcanic rocks based on the total alkali silica diagram. Journal of Petrology. 27, 745-750.

Le Guern, F., Carbonelle, J., Tazieff, H., 1979. Erte 'Ale lava lake: Heat and gas transfer to the atmosphere, J. Volcanol. Geotherm. Res. 6, 27-48.

Loomis, T.P., Welber, P.W., 1982. Crystallization processes in the Rocky Hill granodiorite pluton, California: an interpretation based on compositional zoning of plagioclase. Contrib. Mineral. Petrol. 81, 230-239.

Marsh, B.D., 1989. Magma chambers. Annu. Rev. Earth. Planet. Sci. 17, 439-474.

McDonough, W.F., Sun, S.-s., 1995. The composition of the Earth. Chemical Geology. 120, 223253.

Metrich, N., Rutherford, M.J., 1998. Low pressure crystallization paths of $\mathrm{H}_{2} \mathrm{O}$-saturated basaltic-hawaiitic melts from Mt. Etna; implications for open-system degassing of basaltic volcanoes. Geochim. Cosmochim. Acta. 62, 1195-1205.

Moore J.A., 1986. Mineralogy, geochemistry and petrogenesis of the lavas of Mount Erebus, Antarctica. Unpublished Master's Thesis, New Mexico Institute of Mining and Technology, Socorro, U.S.A.

Nakamura, M., 1995. Continuous mixing of crystal mush and replenished magma in the ongoing Unzen eruption. Geology 23, 807-810.

Nekvasil, H., 1992. Tertiary feldspar crystallization in high-temperature felsic magmas. American Mineralogist. 77, 592-604.

Oppenheimer, C., McGonigle, A.J.S., Allard, P., Wooster, M.J., Tsanev, V., 2004. Sulfur, heat, and magma budget of Erta 'Ale lava lake, Ethiopia. Geology 32, 509-512.

Panter, K.S., Blusztajn, J., Hart, S.R., Kyle, P.R., Esser, R., McIntosh, W.C., 2006. The Origin of HIMU in the SW Pacific: Evidence from Intraplate Volcanism in Southern New Zealand and Subantarctic Islands. Journal of Petrology 47, 1673-1704). 
Pearce, T. H., 1994. Recent work on oscillatory zoning in plagioclase. In: Parsons, I (ed.) Feldspars and their reactions. NATO ASI Series. 421, 313-349.

Reagan, M., Gill, J., Malavassi, E., Garcia, M. O., 1987. Changes in magma composition at Arenal volcano, Costa Rica, 1968-1985: Real-time monitoring of open-system differentiation. Bull. Volcanol. 49, 415-434.

Seaman, S.J., Dyar, M.D., Marinkovic, N., Dunbar, N.W., 2006. An FTIR study of hydrogen in anorthoclase and associated melt inclusions. American Mineralogist. 91, 12-20.

Sims, K.W.W., Blichert_Toft, J., Kyle, P.R., Pichat, S., Gauthier, P-J., Blusztajn, J., Kelly, P., Ball. L., Layne, G., 2008a. A Sr, Nd, Hf, and Pb isotope perspective on the genesis and long-term evolution of alkaline magmas from Erebus volcano, Antarctica. J. Volcanol. Geotherm. Res. (this issue).

Sims, K.W.W., et al ., 2008b. U-series evolution of Erebus lavavs. J. Volcanol. Geotherm. Res. (this issue).

Sims, K.W.W., DePaolo, D.J., 1997. Inferences about mantle magma sources from incompatible element concentration ratios in oceanic basalts. Geochim. Cosmochim. Acta. 61, 765-784.

Stevenson, D.S., Blake, S., 1998. Modeling the dynamics and thermodynamics of volcanic degassing. Bull. Volcanol. 60, 307-317.

Stoiber, R., Williams, S., Huebert, B., 1986. Sulfur and halogen gases at Masaya caldera complex, Nicaragua: Total flux and variations with time. J. Geophys. Res. 91, 2215-2231.

Stormer, J.C., 1983. The effects of recalculation on estimates of temperature and oxygen fugacity from analyses of multicomponent iron-titanium oxides. American Mineralogist. 68, 586-594.

Streck, M.J., Dungan, M.A., Bussy, F., Malavassi, E., 2005. Mineral inventory of continuously erupting basaltic andesites at Arenal volcano, Costa Rica: implications for interpreting monotonous, crystal-rich, mafic arc stratigraphies. J. Volcanol. Geotherm. Res. 140, 133-155.Sun, S.-S., Hanson, G.N., 1975. Origin of Ross Island basanitoids and limitations upon the heterogeneity of mantle sources for alkali basalts and nephelinites. Contrib. Miner. Petrol. 54, 139-55.

Sun, S.-S., Hanson, G.N., 1976. Rare earth element evidence for differentiation of McMurdo Volcanics, Ross Island, Antarctica. Contrib. Miner. Petrol. 54, 139155. 
Sun, S.-S., McDonough, W.F., 1989. Chemical and isotopic systematics of oceanic basalts: implications for mantle compositions and processes. In: Saunders, A.D., Norry, M.J. (Eds.), Magmatism in Ocean Basins. Geol. Soc. London, Spec. Publ. 42, 313-345.

Tazieff, H., 1984. Nyiragongo: Renewed activity of the lava lake. J. Volcanol. Geotherm. Res., 20, 267-280.

Tilling, R.I., 1987. Fluctuations in surface height of active lava lakes during 19721974 Mauna Ulu eruption, Kilauea Volcano, Hawaii. J. Geophys. Res. 92, 13721-13730.

Tuttle, O.F., Bowen, N.L., 1958. Origin of granite in the light of experimental studies. Geological Society of America, Boulder, Colorado. 153 pp.

Venezky, D.Y., Rutherford, M.J., 1999. Petrology and Fe-Ti oxide reequilibration of the 1991 Mount Unzen mixed magma. J. Volcanol. Geotherm. Res. 89, 213230.

Wardell, L.J., Kyle, P.R., Chaffin, C., 2004. Carbon dioxide and carbon monoxide emission rates from an alkaline intra-plate volcano: Mt. Erebus, Antarctica. J. Volcanol. Geotherm. Res. 131, 109-121.

Wen, S., Nekvasil, H., 1994. SOLVCALC; an interactive graphics program package for calculating the ternary feldspar solvus and for two-feldspar geothermometry. Computers and Geosciences. 20, 1025-1040.

Wilson, M., 1989. Igneous Petrogenesis. Unwin Hyman Ltd., London, England. $466 \mathrm{pp}$.

Witter, J.B., Kress, V.C., Delmelle, P., Stix, J., 2004. Volatile degassing, petrology, and magma dynamics of the Villarrica Lava Lake, Southern Chile. J. Volcanol. Geotherm. Res. 134, 303-337. 


\section{Figure Captions}

Figure 1. Geologic map of the summit of Erebus volcano showing lava flow units, their names and ${ }^{40} \mathrm{Ar} /{ }^{39} \mathrm{Ar}$ ages and $2 \sigma$ errors in ka (Harpel et al. 2004, Kelly et al., 2008). The circular outer rim of the summit area was formed by a caldera collapse between 80 and $24 \mathrm{ka}$. A remnant from a younger nested caldera collapse between 25 to $11 \mathrm{ka}$ is marked. The outer limit in the distribution of lava bombs erupted in late 1984 and some unknown earlier eruptive episode are shown.

Figure 2. Total alkali-silica classification (LeBas et al., 1986) of Erebus volcano lavas and recently erupted lava bombs. $\mathrm{MG}=$ matrix glass. $\mathrm{WR}=$ whole rock.

Figures 3. Trace element variations in whole rock $(\mathrm{WR})$ lava samples $(n=11)$ erupted in the last $\sim 17 \mathrm{ka}$ and matrix glass (MG) from lava bombs erupted 1972 to $2004(\mathrm{n}=27)$. The composition of sample DVDP-2 105.53, a 1.3 Ma basanite assumed to be parental to the Erebus Lineage (Kyle et al., 1992; Esser et al., 2004) is shown for comparison against the evolved phonolites.

(a) Normalized to primitive mantle (McDonough and Sun, 1995). (b) Rare earth elements (REE) normalized to carbonaceous chrondrites (McDonough and Sun, 1995).

Figure 4. Plot of Ba versus $\mathrm{Zr}$ variations in whole rock (WR) lava samples and matrix glass (MG) from recently erupted lava bombs. Analytical errors are approximately the same size as symbols. Most chemical variation in the Erebus Lineage (EL) can be explained by Rayleigh crystallization. The compositional range in phonolite summit lavas from this study (red circles) can be explained by variations in the modal proportion of feldspar. Matrix glass from recently erupted lava bombs mostly reflects the crystallizaiton of anorthoclase and shows no significant 
chemical variation. The Rayleigh crystallization trend was calculated in two stages using lava and glass compositional data from this study and Kyle et al. (1992): (I) basanite (83435) to phonolite using $\mathrm{D}_{\mathrm{Zr}}=0.15, \mathrm{DBa}_{\mathrm{Ba}}=0.44$; (II) phonolite to matrix glass $\mathrm{Dzr}=0.15, \mathrm{DBa}_{\mathrm{Ba}}=3.00$. Feldspar Ba composition from Table 4 and Zr from Dunbar et al. (1994).

Figure 5. Selected incompatible element ratios versus $\mathrm{SiO}_{2}$ for Erebus volcano lavas (Kyle et al. 1992) and summit lavas and glasses from bombs (this study). Symbols are the same as Figure 2.

Figure 6. Concentrations of selected major element oxides (wt. \%) in matrix glass from lava bombs erupted between 1972 and 2004. Determinations were made by EMP and are shown with $2 \sigma$ analytical uncertainty. Data from Table 2.

Figure 7. Concentrations of selected trace elements (ppm) in matrix glass from lava bombs erupted between 1972 and 2004. Determinations were made by ICP-MS. Concentrations are shown with either $3 \%$ relative analytical uncertainty, or the estimated uncertainty, whichever is larger. Data from Table 2.

Figure 8. Electron microprobe analyses of feldspar compositions for traverses across 8 single crystals separated from bombs samples 84505, 85010, Dec1999, and Dec2000. The isothermal solvus is shown for reference and calculated at $900^{\circ} \mathrm{C}$ and 1 bar using the model of Elkins and Grove (1990) and computer program SOLVCALC (Wen and Nekvasil, 1994). An = anorthite, $\mathrm{Ab}=$ albite, $\mathrm{Or}=$ orthoclase. 
Figure 9. Results of a rim-to-rim electron microprobe traverse of crystal 85010-01 shown with $2 \sigma$ uncertainties (Table 4). The crystal was taken from lava bomb 85010 and was erupted in $\sim$ Dec 1985. The crystal was cut perpendicular to the c-axis for analysis. The traverse was made from rim-to-rim through the core of the crystal and perpendicular to zoning. Average step size is $40 \mu \mathrm{m}$.

Figure 10. Plot of oxygen fugacity $\left(\mathrm{O}_{2}\right)$ versus temperature. Oxygen fugacity is shown relative to the fayalite-magnetite-quartz buffer (FMQ). An estimate for the Erebus volcano lava lake is shown. It was calculated using the QUILF computer program (Anderson et al., 1993), assuming $\mathrm{T}=1000^{\circ} \mathrm{C}, \mathrm{P}=1 \mathrm{bar}$ and using analyses of olivine, titanomagnetite and clinoyroxene (Table 3). The plotted symbol is larger than calculated errors. Ülvospinel and QUILF oxygen buffer is from Anderson and Lindsley (1988). Fayalite-magnetite-quartz (FMQ), hematite-magnetite (HM) and quartz-iron-fayalite (QIF) buffer after Frost et al. (1988). $\mathrm{SO}_{2}-\mathrm{H}_{2} \mathrm{~S}$ equilibrium curve is from Goff et al. (2001).

\section{Table Captions}

Table 1. Whole-rock analyses of phonolite lavas erupted in the last $\sim 17 \mathrm{ka}$ and one recently erupted lava bomb erupted from Mt. Erebus volcano.

Table 2. Major and trace element concentrations of matrix glass separated from lava bombs erupted from Erebus volcano between December 1972 and January 2004.

Table 3. Representative analyses of olivine, clinopyroxene, titanomagnetite, fluorapatite, and pyrrhotite in lava bombs erupted from Erebus volcano between December 
1972 and January 2004 as determined by electron microprobe.

Table 4. Representative analyses of anorthoclase feldspar in lava bombs recently erupted from Erebus volcano as determined by EMP.

Table 5. Modal mineralogy of recently erupted lava bombs calculated by mass-balance. 


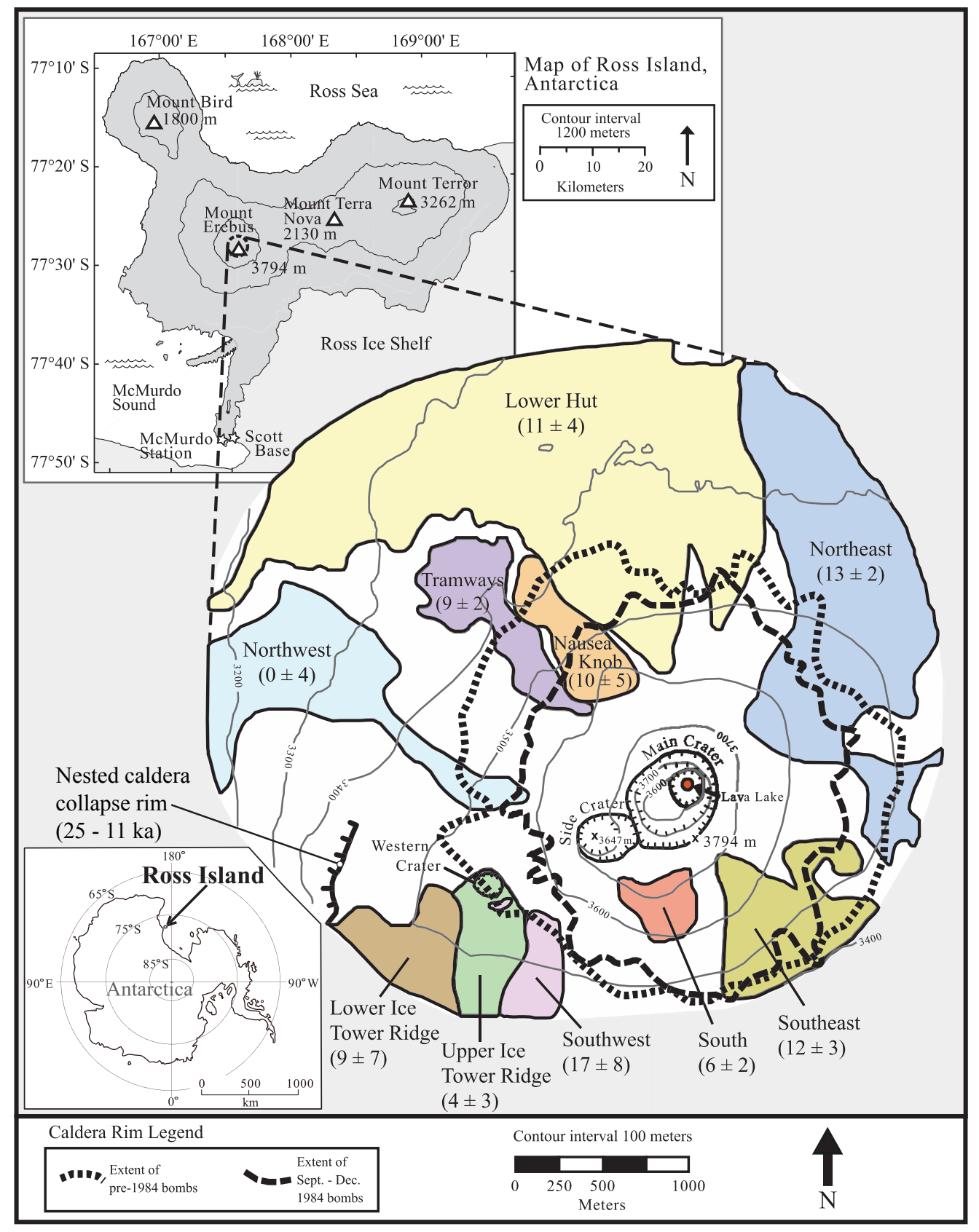




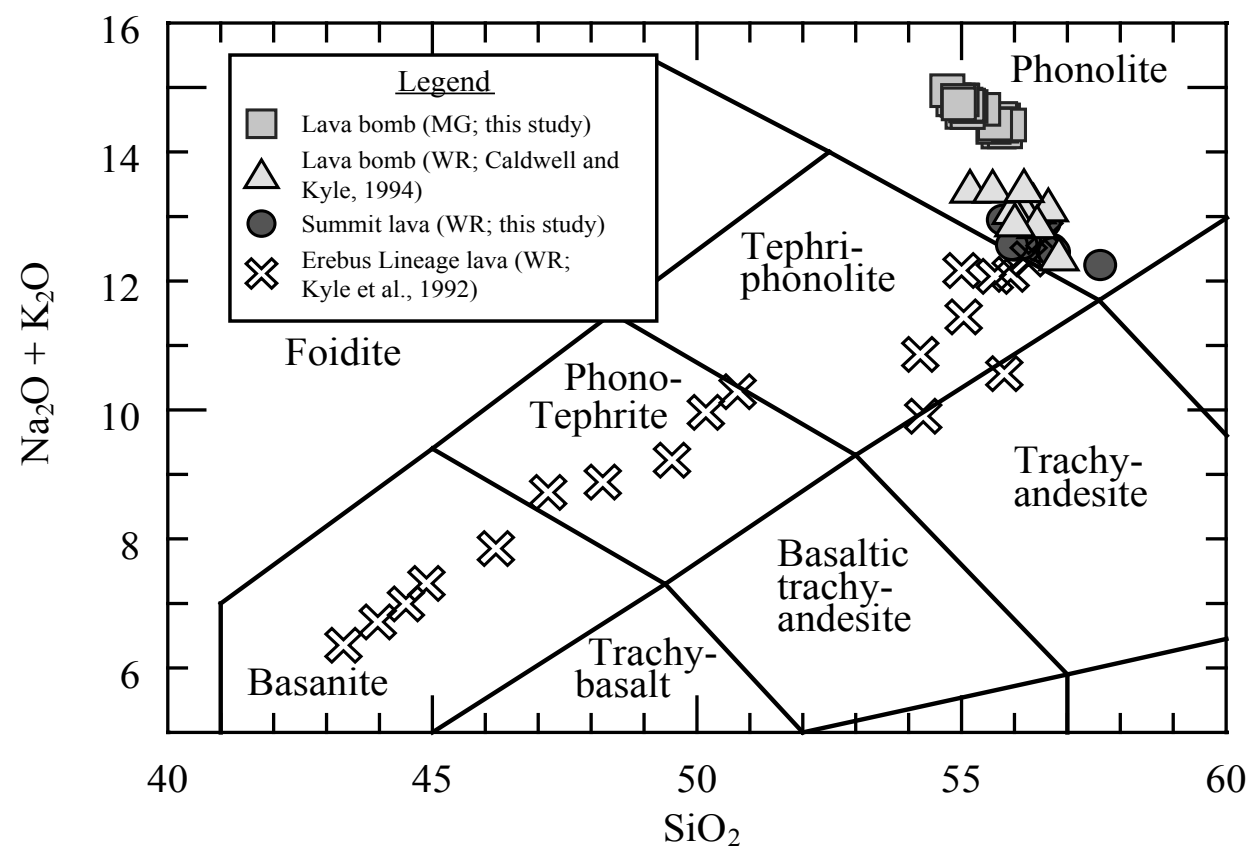



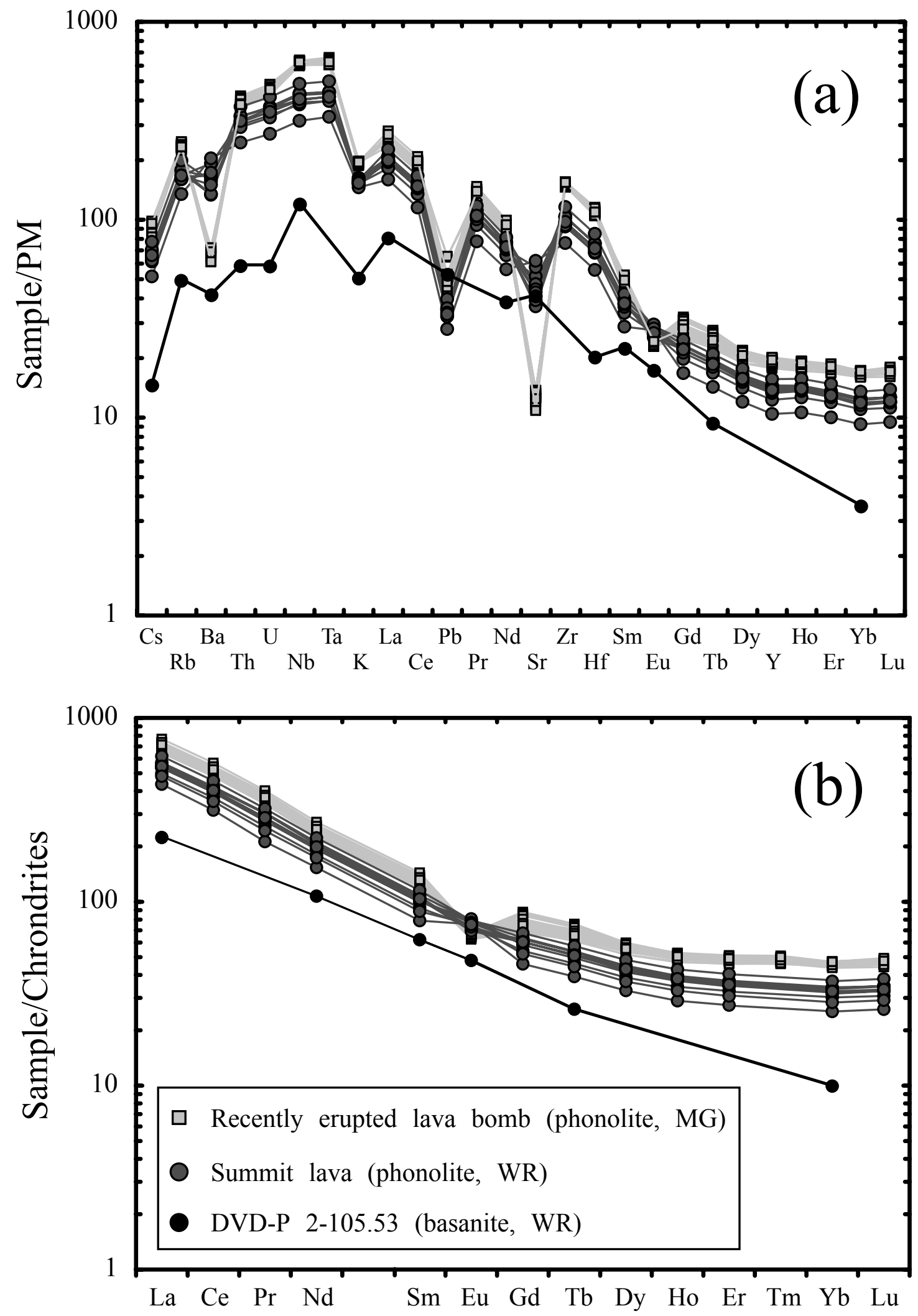


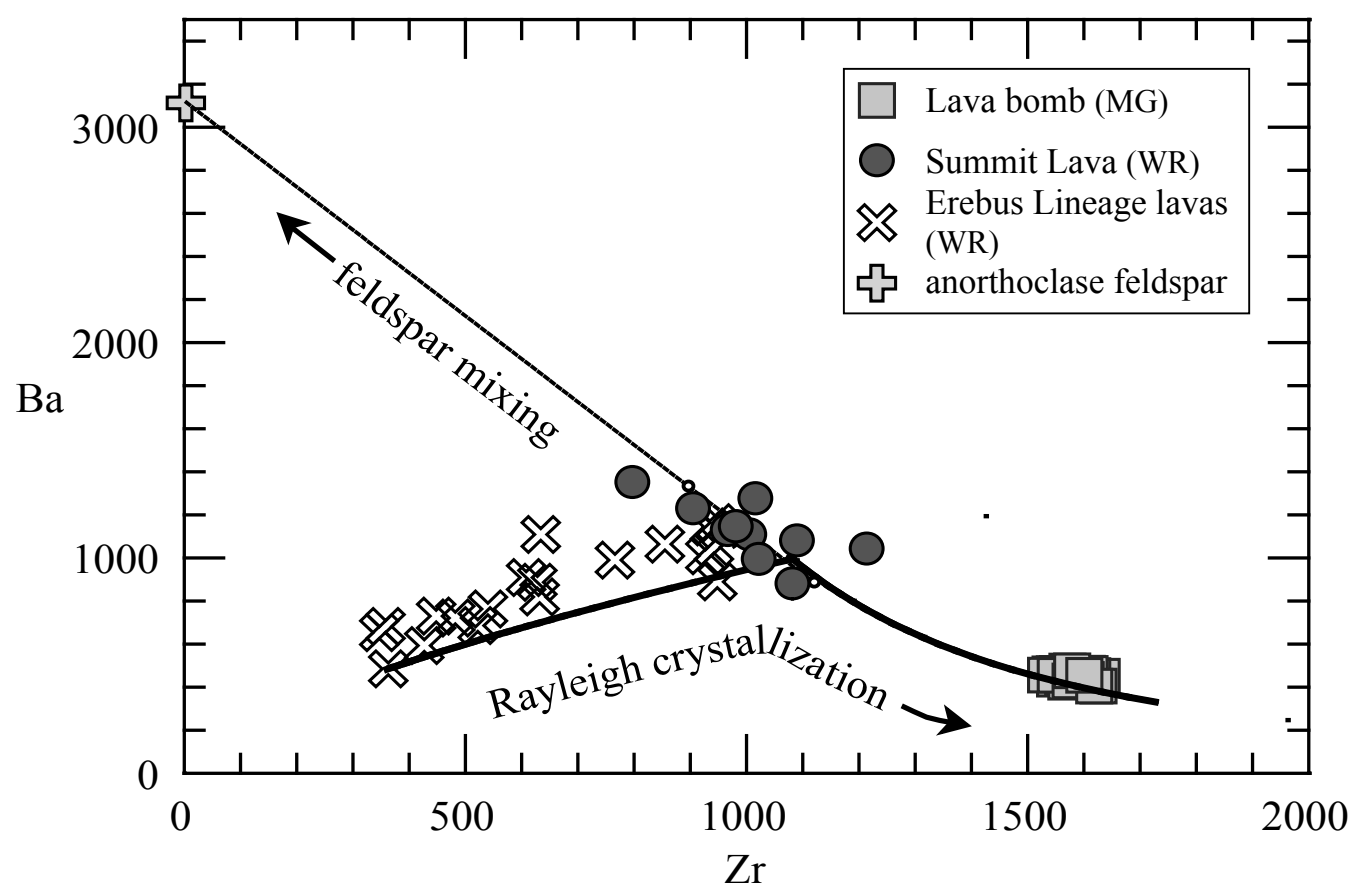




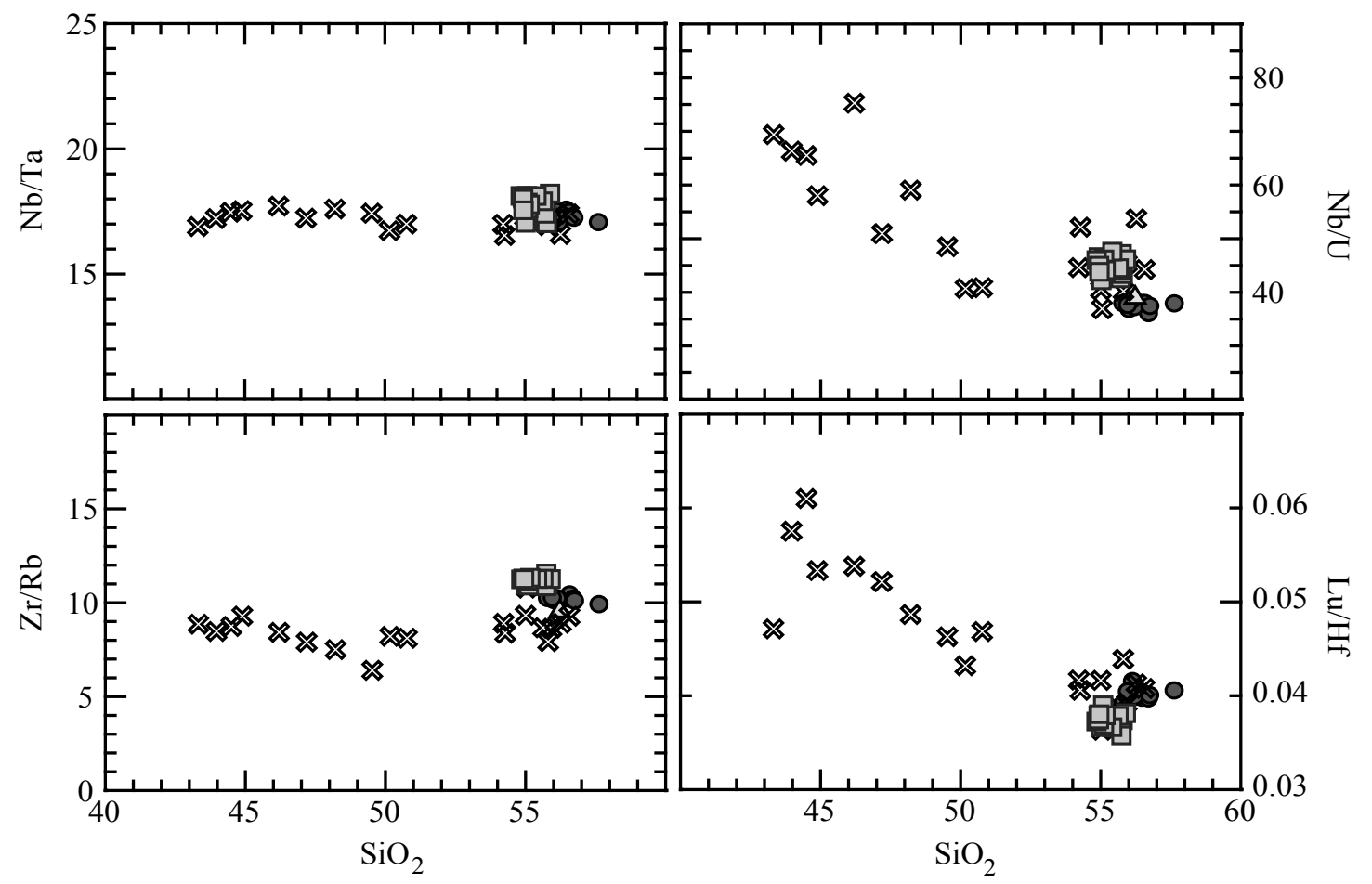



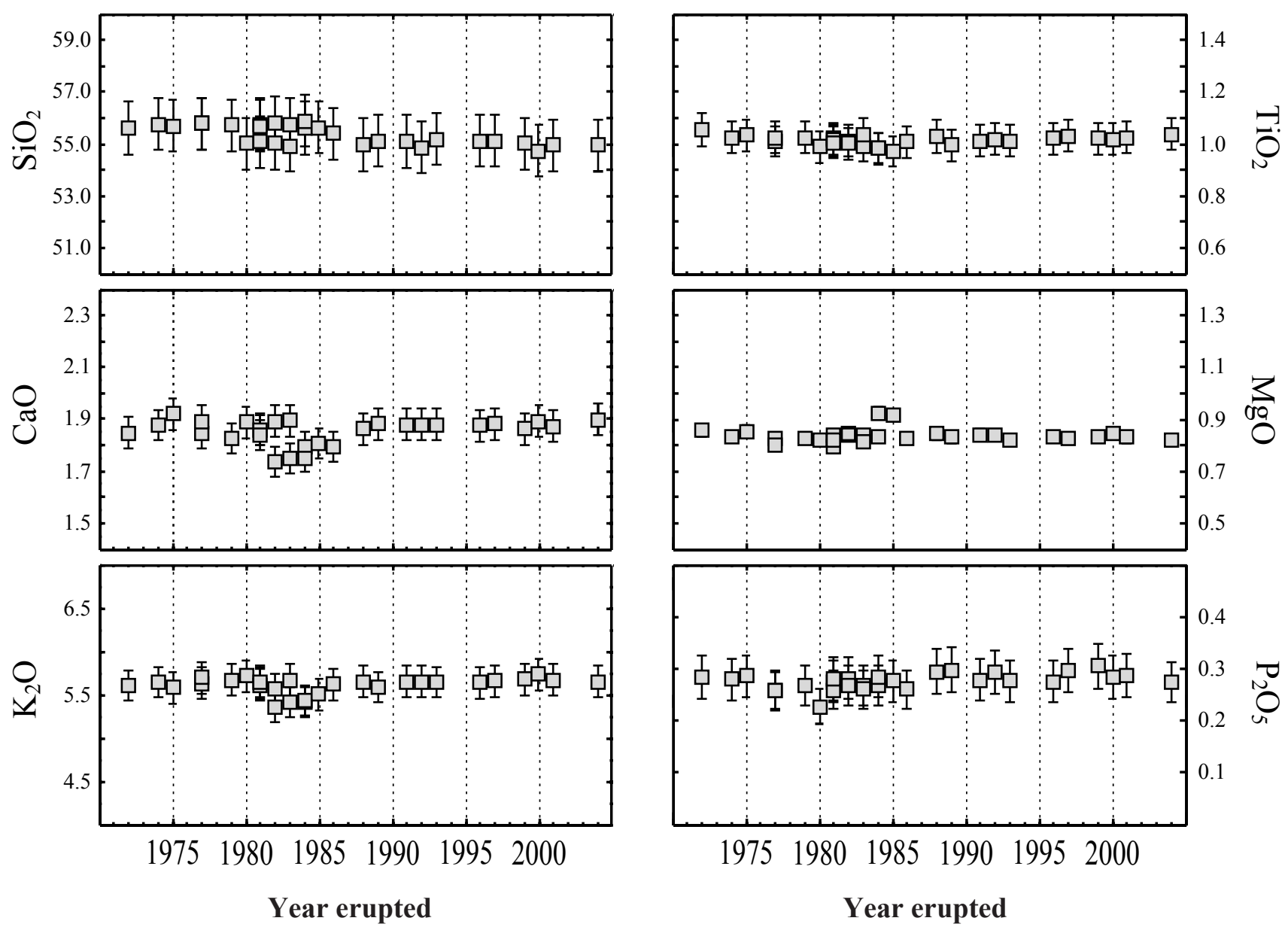

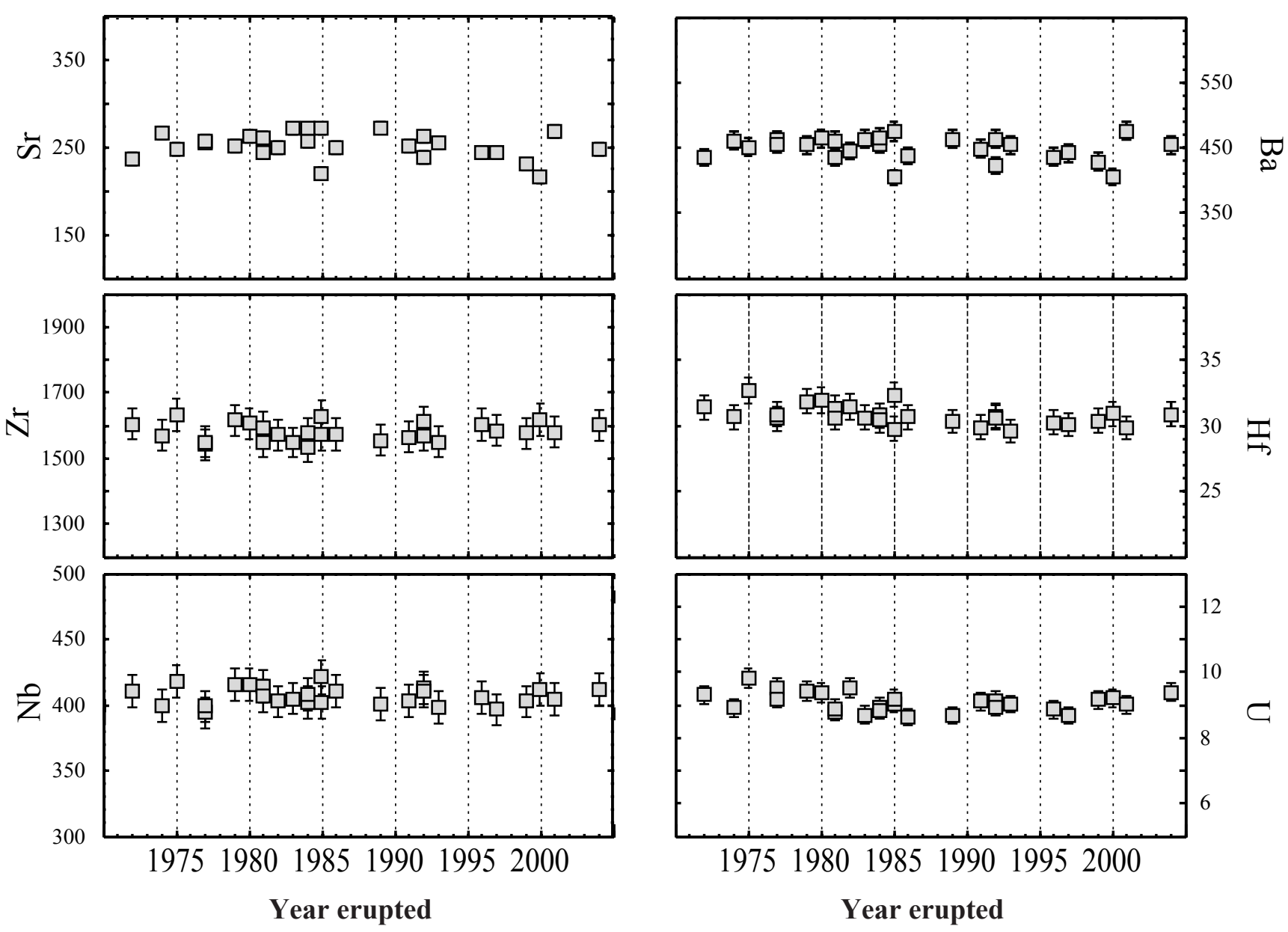

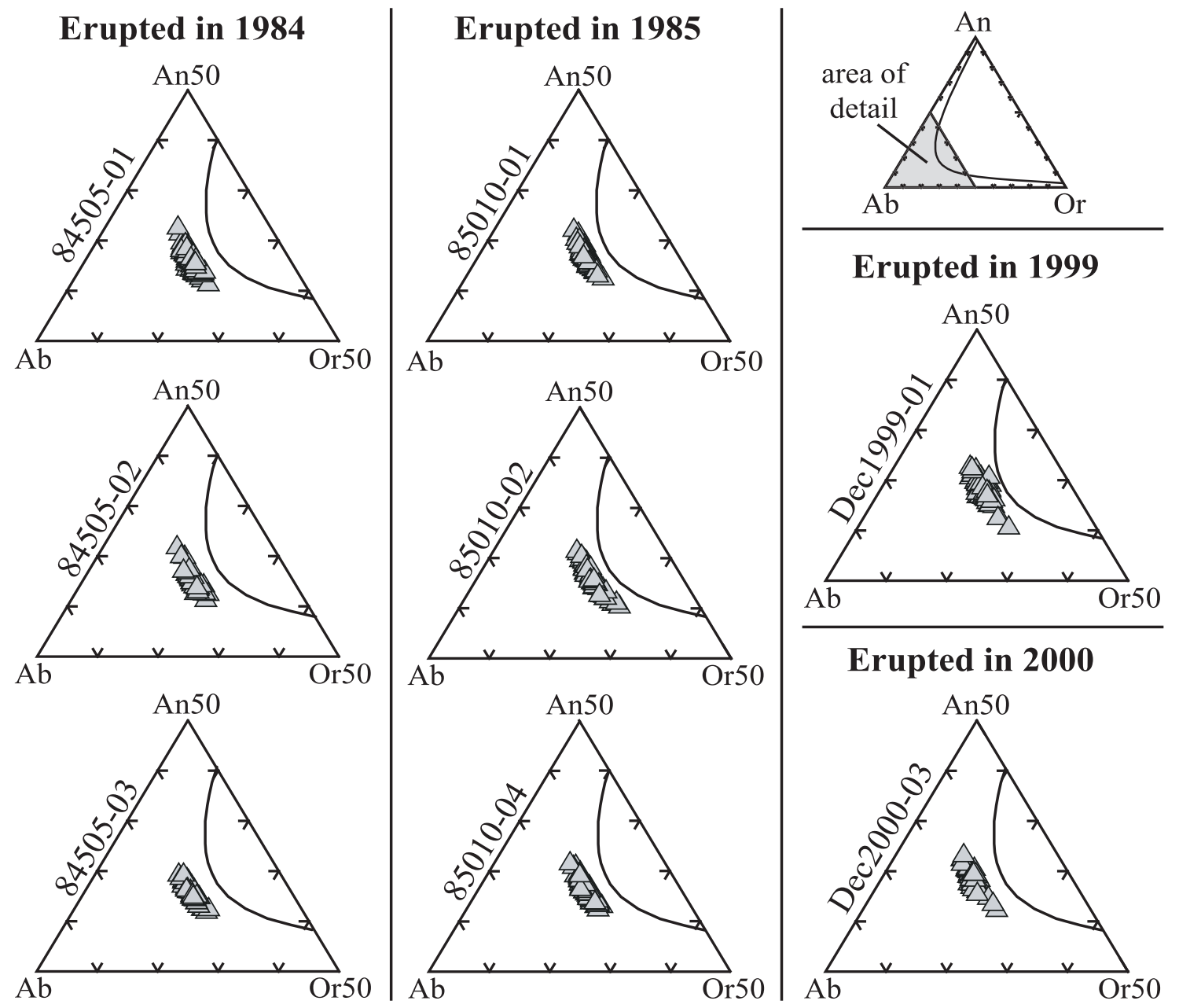

\section{Erupted in 1999}
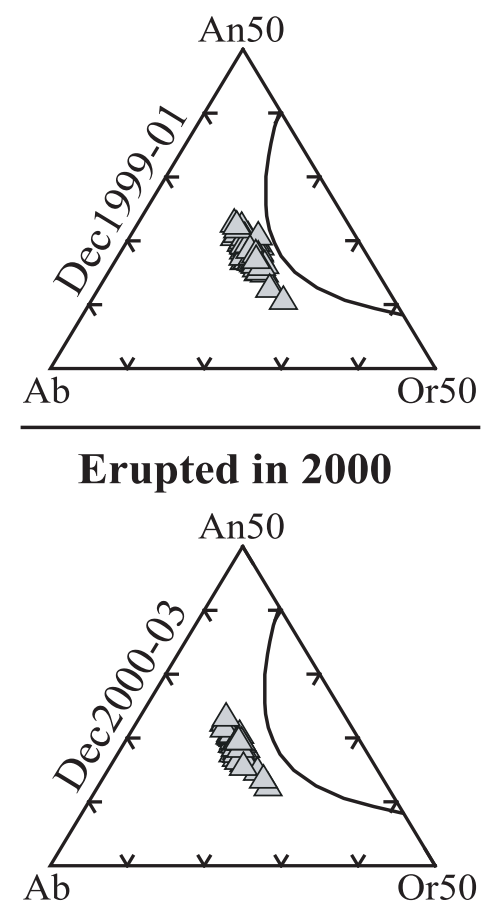


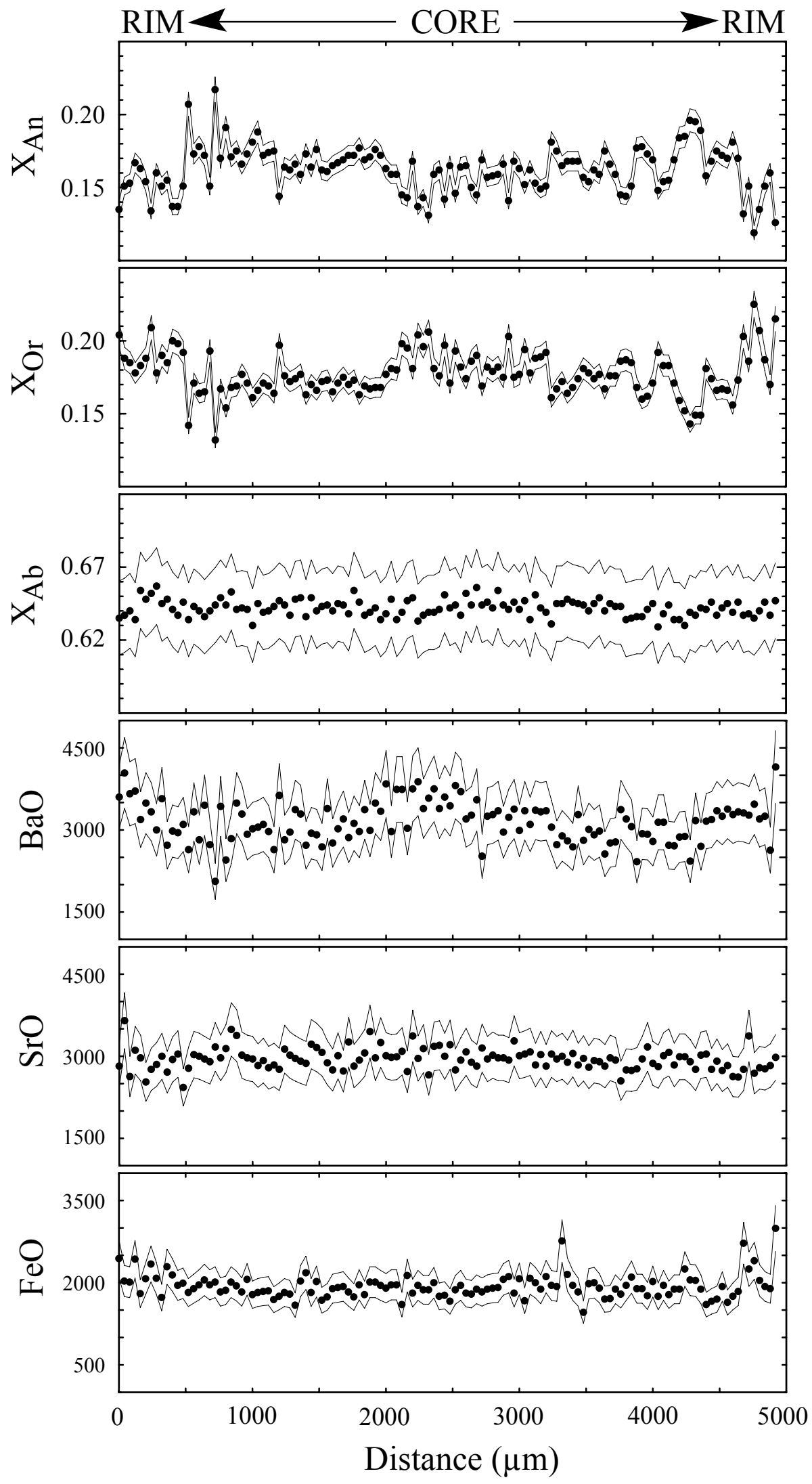




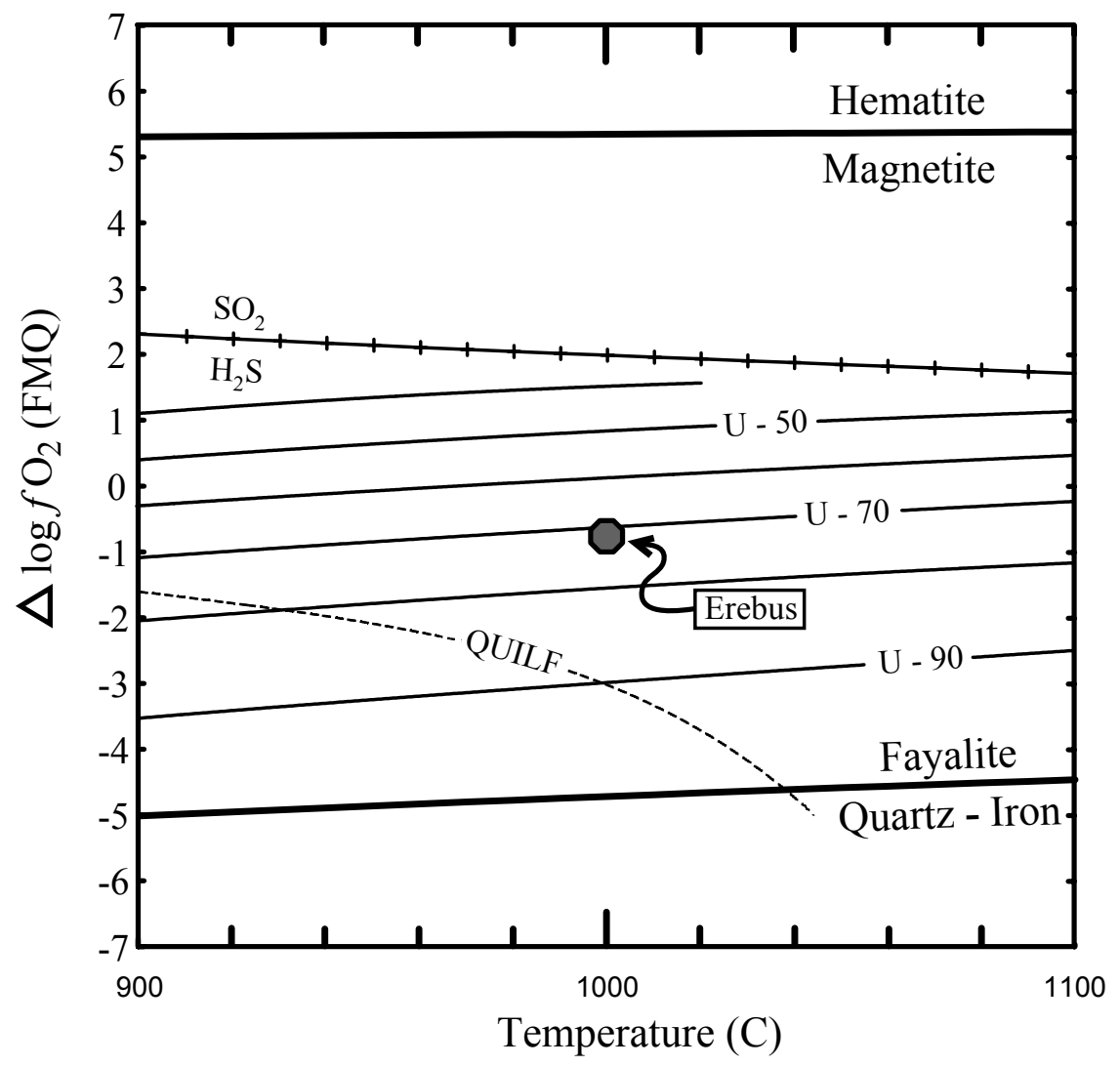


Table 1. Whole-rock analyses of phonolite lavas erupted in the last $\sim 17 \mathrm{ka}$ and one recently erupted lava bomb erupted from Mt. Erebus volcano.

\begin{tabular}{|c|c|c|c|c|c|c|c|c|c|c|c|c|}
\hline Sample & E87066 & E87030 & E87085 & E87020 & E87034 & E87035 & E87004 & E87054 & E87083 & E87051 & E87040 & $\begin{array}{c}97018^{*} \\
\text { erupted } \\
\text { 21-Dec-1997 }\end{array}$ \\
\hline Location & $\begin{array}{l}\text { Southwest } \\
\text { flow }\end{array}$ & $\begin{array}{c}\text { Northeast } \\
\text { flow }\end{array}$ & $\begin{array}{l}\text { Southeast } \\
\text { flow }\end{array}$ & $\begin{array}{l}\text { Lower Hut } \\
\text { flow }\end{array}$ & $\begin{array}{l}\text { Lower Hut } \\
\text { flow }\end{array}$ & Nausea knob & $\begin{array}{c}\text { Tramways } \\
\text { flow }\end{array}$ & $\begin{array}{c}\text { Lower Ice } \\
\text { Tower Ridge }\end{array}$ & South flow & $\begin{array}{c}\text { Upper Ice } \\
\text { Tower Ridge }\end{array}$ & $\begin{array}{l}\text { Northwest } \\
\text { flow }\end{array}$ & $\begin{array}{l}\text { collected from } \\
\text { crater rim }\end{array}$ \\
\hline $\mathrm{SiO}_{2}(\mathrm{wt} \%)$ & 56.02 & 56.49 & 56.59 & 56.05 & 55.80 & 56.72 & 57.64 & 56.22 & 56.15 & 55.97 & 56.77 & 56.23 \\
\hline $\mathrm{TiO}_{2}$ & 0.98 & 1.08 & 1.13 & 1.11 & 1.10 & 1.00 & 0.89 & 1.09 & 1.00 & 1.11 & 0.96 & 0.99 \\
\hline $\mathrm{Al}_{2} \mathrm{O}_{3}$ & 19.88 & 19.73 & 19.88 & 19.71 & 19.62 & 19.94 & 20.27 & 19.60 & 19.38 & 19.61 & 20.11 & 19.82 \\
\hline $\mathrm{Fe}_{2} \mathrm{O}_{3}{ }^{\mathrm{T}}$ & 5.22 & 5.81 & 6.19 & 5.92 & 5.87 & 5.27 & 4.68 & 5.76 & 5.62 & 5.98 & 4.97 & 5.35 \\
\hline $\mathrm{MnO}$ & 0.21 & 0.24 & 0.26 & 0.24 & 0.24 & 0.23 & 0.19 & 0.23 & 0.24 & 0.24 & 0.20 & 0.23 \\
\hline $\mathrm{MgO}$ & 0.91 & 1.03 & 1.03 & 0.99 & 0.98 & 0.94 & 0.83 & 0.89 & 0.97 & 1.03 & 0.85 & 0.88 \\
\hline $\mathrm{CaO}$ & 2.86 & 2.90 & 2.74 & 2.79 & 2.78 & 2.93 & 3.00 & 2.86 & 2.75 & 2.82 & 2.91 & 2.68 \\
\hline $\mathrm{K}_{2} \mathrm{O}$ & 4.40 & 4.46 & 4.71 & 4.59 & 4.58 & 4.38 & 4.21 & 4.47 & 4.45 & 4.43 & 4.33 & 4.51 \\
\hline $\mathrm{Na}_{2} \mathrm{O}$ & 8.13 & 8.05 & 8.18 & 8.32 & 8.35 & 8.10 & 8.02 & 8.16 & 8.10 & 8.11 & 8.10 & 8.38 \\
\hline $\mathrm{P}_{2} \mathrm{O}_{5}$ & 0.42 & 0.47 & 0.48 & 0.47 & 0.48 & 0.43 & 0.39 & 0.46 & 0.44 & 0.48 & 0.41 & 0.41 \\
\hline L.O.I. & -0.15 & -0.18 & -0.08 & 0.10 & 0.33 & -0.11 & -0.12 & -0.21 & -0.14 & -0.14 & -0.09 & -0.16 \\
\hline Total & 98.88 & 100.08 & 101.10 & 100.29 & 100.13 & 99.83 & 100.00 & 99.53 & 98.96 & 99.65 & 99.52 & 99.61 \\
\hline $\mathrm{TiO}_{2}(\mathrm{wt} \%)$ & 1.00 & 1.22 & 1.06 & 1.12 & 1.31 & 1.11 & 0.90 & 1.15 & 1.02 & 1.12 & 0.99 & \\
\hline Li (ppm) & 17.8 & 23.2 & 26.3 & 27.6 & 30.6 & 26.4 & 19.9 & 24.2 & 20.2 & 22.7 & 21.1 & \\
\hline $\mathrm{Be}$ & 8.66 & 9.64 & 9.35 & 9.50 & 10.82 & 9.24 & 7.07 & 8.70 & 8.29 & 8.82 & 7.78 & \\
\hline $\mathrm{Sc}$ & 3.07 & 3.29 & 3.40 & 3.24 & 4.00 & 3.12 & 2.50 & 3.63 & 3.49 & 3.12 & 3.12 & \\
\hline V & 4.97 & 7.79 & 6.08 & 5.88 & 7.31 & 6.19 & 5.05 & 7.72 & 5.66 & 6.88 & 5.20 & 8.5 \\
\hline Co & 10.4 & 10.1 & 9.06 & 10.2 & 13.9 & 12.6 & 18.2 & 9.24 & 8.91 & 10.7 & 11.0 & \\
\hline $\mathrm{Ni}$ & 1.9 & 0.61 & 0.64 & 0.80 & 0.98 & 0.88 & 0.61 & 0.58 & 0.76 & 0.54 & 0.51 & 4.5 \\
\hline $\mathrm{Cu}$ & 6.8 & 5.6 & 5.1 & 5.4 & 6.2 & 5.6 & 4.3 & 5.3 & 5.1 & 5.1 & 5.0 & 4.5 \\
\hline $\mathrm{Zn}$ & 115 & 138 & 128 & 129 & 151 & 136 & 98 & 128 & 128 & 128 & 107 & 127 \\
\hline $\mathrm{Ga}$ & 22 & 26 & 23 & 22 & 27 & 24 & 23 & 23 & 23 & 22 & 22 & 27.2 \\
\hline $\mathrm{Rb}$ & 95.8 & 107 & 104 & 107 & 119 & 100 & 80.8 & 99.2 & 96.3 & 100 & 90.0 & 107 \\
\hline $\mathrm{Sr}$ & 1028 & 939 & 726 & 780 & 917 & 1145 & 1234 & 941 & 886 & 854 & 1120 & 914 \\
\hline $\mathrm{Y}$ & 52.9 & 62.4 & 62.2 & 60.5 & 67.3 & 57.2 & 44.9 & 58.2 & 58.7 & 59.3 & 50.4 & 55.9 \\
\hline $\mathrm{Zr}$ & 969 & 1092 & 1083 & 1084 & 1216 & 1018 & 799 & 1007 & 983 & 1024 & 907 & 1016 \\
\hline $\mathrm{Nb}$ & 252 & 286 & 281 & 284 & 320 & 266 & 208 & 264 & 257 & 267 & 236 & 261 \\
\hline Cs & 1.29 & 1.47 & 1.44 & 1.48 & 1.62 & 1.35 & 1.08 & 1.35 & 1.31 & 1.39 & 1.23 & \\
\hline $\mathrm{Ba}$ & 1124 & 1075 & 881 & 889 & 1037 & 1271 & 1346 & 1103 & 1141 & 989 & 1224 & 1129 \\
\hline $\mathrm{La}$ & 118 & 136 & 133 & 130 & 147 & 127 & 103 & 127 & 128 & 129 & 114 & \\
\hline $\mathrm{Ce}$ & 226 & 259 & 255 & 249 & 279 & 241 & 193 & 242 & 246 & 247 & 215 & \\
\hline $\operatorname{Pr}$ & 23.8 & 28.3 & 28.0 & 26.6 & 29.8 & 25.5 & 19.7 & 26.4 & 26.5 & 26.6 & 22.6 & \\
\hline $\mathrm{Nd}$ & 82.5 & 96.3 & 93.5 & 90.9 & 102 & 88.1 & 70.2 & 89.9 & 90.4 & 90.8 & 79.3 & \\
\hline $\mathrm{Sm}$ & 13.7 & 16.1 & 15.8 & 15.3 & 17.1 & 14.7 & 11.7 & 15.1 & 15.2 & 15.3 & 13.1 & \\
\hline $\mathrm{Eu}$ & 4.12 & 4.44 & 3.97 & 3.91 & 4.45 & 4.55 & 4.26 & 4.31 & 4.34 & 4.11 & 4.24 & \\
\hline $\mathrm{Gd}$ & 10.8 & 12.7 & 12.5 & 12.0 & 13.4 & 11.6 & 9.1 & 12.1 & 12.0 & 12.0 & 10.4 & \\
\hline $\mathrm{Tb}$ & 1.67 & 1.94 & 1.92 & 1.86 & 2.07 & 1.79 & 1.41 & 1.85 & 1.85 & 1.84 & 1.60 & \\
\hline Dy & 9.52 & 11.0 & 10.8 & 10.7 & 11.9 & 10.2 & 8.09 & 10.5 & 10.4 & 10.6 & 9.07 & \\
\hline Но & 1.88 & 2.16 & 2.14 & 2.12 & 2.34 & 2.03 & 1.58 & 2.06 & 2.06 & 2.08 & 1.80 & \\
\hline $\mathrm{Er}$ & 5.23 & 5.95 & 5.90 & 5.80 & 6.47 & 5.55 & 4.39 & 5.63 & 5.59 & 5.67 & 4.91 & \\
\hline $\mathrm{Yb}$ & 4.86 & 5.52 & 5.45 & 5.39 & 5.96 & 5.23 & 4.07 & 5.15 & 5.09 & 5.25 & 4.56 & \\
\hline $\mathrm{Lu}$ & 0.757 & 0.854 & 0.859 & 0.851 & 0.937 & 0.809 & 0.640 & 0.805 & 0.805 & 0.820 & 0.716 & \\
\hline Hf & 19.2 & 21.5 & 21.4 & 21.4 & 24.0 & 20.4 & 15.8 & 20.2 & 19.4 & 20.3 & 17.9 & \\
\hline Ta & 14.7 & 16.3 & 16.1 & 16.3 & 18.5 & 15.4 & 12.2 & 15.5 & 14.7 & 15.5 & 13.7 & \\
\hline $\mathrm{Pb}$ & 4.91 & 5.29 & 5.20 & 5.28 & 5.95 & 5.36 & 4.20 & 5.08 & 4.86 & 4.99 & 4.75 & 5.8 \\
\hline $\mathrm{Th}$ & 24.0 & 26.2 & 26.6 & 26.5 & 29.6 & 25.1 & 19.5 & 24.7 & 23.3 & 25.1 & 22.0 & 26.4 \\
\hline $\mathrm{U}$ & 6.85 & 7.55 & 7.42 & 7.52 & 8.45 & 7.39 & 5.50 & 7.11 & 6.66 & 7.11 & 6.32 & 6.7 \\
\hline
\end{tabular}

Age $={ }^{40} \mathrm{Ar} /{ }^{39} \mathrm{Ar}$ ages and 2-sigma errors from Harpel et al. (2004), except E87040 from Kelly et al. (this volume). L.O.I. = Loss on ignition. Major elements analyzed by Philips PW2400 X-ray fluorescence (XRF) spectrometer at New Mexico Tech (NMT) (Hallett and Kyle, 1993). Typical major element XRF analytical precision is $<1 \%$. Trace elements and $\mathrm{TiO} 2$ analyzed by VG PQ ExCell quadrupole ICP-MS at Boston University following the procedures of Kelley et al. (2003) (except 97018*). Analytical precision for trace elements is $<3 \%$. *Previously unpublished whole rock analysis of lava bomb from Eschenbacher (1998) for comparison; major and trace elements by XRF at NMT (typical trace element precision $<2 \%$ ). 
Table 2. Major and trace element concentrations of matrix glass separated from lava bombs erupted from Erebus volcano between December 1972 and January 2004.

\begin{tabular}{|c|c|c|c|c|c|c|c|c|c|c|c|c|c|c|c|c|c|c|c|c|c|c|c|c|c|}
\hline $\begin{array}{l}\text { Eruption } \\
\text { date } \\
\text { Sample }\end{array}$ & $\begin{array}{c}26 \mathrm{Dec} \\
1972 \\
25724 \mathrm{G}\end{array}$ & $\begin{array}{c}\text { Dec } 1974 \\
2 \mathrm{E} 2 \mathrm{G}\end{array}$ & $\begin{array}{c}\text { Dec } 1974 \\
25721 \mathrm{G}\end{array}$ & $\begin{array}{c}\text { Dec } 1975 \\
25723 \mathrm{G}\end{array}$ & $\begin{array}{c}\sim \text { Nov } \\
1977 \\
77015 \mathrm{G}\end{array}$ & $\begin{array}{c}\text { Nov } 1977 \\
77016 \mathrm{G}\end{array}$ & $\begin{array}{c}\text { Nov } 1977 \\
78325 \mathrm{G}\end{array}$ & $\begin{array}{c}26 \mathrm{Dec} \\
1979 \\
79302 \mathrm{G}\end{array}$ & $\begin{array}{c}\text { Nov } 1980 \\
80300 \mathrm{G}\end{array}$ & $\begin{array}{c}\sim \text { Nov } \\
1981 \\
81003 \mathrm{G}\end{array}$ & $\begin{array}{c}\text { Nov } 1981 \\
81401 \mathrm{G}\end{array}$ & $\begin{array}{c}\sim \text { Nov } \\
1981 \\
81410 \mathrm{G}\end{array}$ & $\begin{array}{c}\text { Dec } 1982 \\
82416 \mathrm{G}\end{array}$ & $\begin{array}{c}\sim \mathrm{Dec} \\
1982 \\
82418 \mathrm{G}\end{array}$ & $\begin{array}{c}\sim \mathrm{Dec} \\
1983 \\
83207 \mathrm{G}\end{array}$ & $\begin{array}{c}\text { Dec } 1983 \\
83220 \mathrm{G}\end{array}$ & $\begin{array}{c}\text { Oct } 1984 \\
84500 \mathrm{G}\end{array}$ & $\begin{array}{c}\text { Dec } 1984 \\
84501 \mathrm{G}\end{array}$ & $\begin{array}{c}\text { Dec } 1984 \\
84505 \mathrm{G}\end{array}$ & $\begin{array}{c}\text { Dec } 1985 \\
85009 \mathrm{G}\end{array}$ & $\begin{array}{c}\sim \mathrm{Dec} \\
1985 \\
85010 \mathrm{G}\end{array}$ & $\begin{array}{c}22 \mathrm{Dec} \\
1986 \\
86022 \mathrm{G}\end{array}$ & $\begin{array}{c}\text { Dec 1988 } \\
88104 \mathrm{G}\end{array}$ & $\begin{array}{c}\text { Dec } 1989 \\
89001 \mathrm{G}\end{array}$ & $\begin{array}{c}\text { Jan } 1991 \\
91101 \mathrm{G}\end{array}$ \\
\hline \multicolumn{26}{|c|}{ Major Element Concentrations (EMP) } \\
\hline $\mathrm{SiO}_{2}(\mathrm{wt} . \%)$ & 55.62 & 55.75 & & 55.70 & 55.78 & & 55.78 & 55.73 & 55.01 & 55.74 & 55.08 & 55.69 & 55.02 & 255.82 & 55.75 & 54.93 & 55.61 & & 55.90 & 55.63 & & 255.41 & 54.97 & 255.12 & 255.09 \\
\hline $\mathrm{TiO}_{2}$ & 1.05 & 1.02 & & 1.03 & 1.01 & & 1.02 & 1.02 & 0.99 & 1.02 & 1.01 & 1.01 & 1.01 & 1.00 & 0.99 & 1.03 & 0.98 & & 0.98 & 0.97 & & 1.01 & 1.03 & 0.99 & 1.01 \\
\hline $\mathrm{Al}_{2} \mathrm{O}_{3}$ & 19.58 & 19.67 & & 19.60 & 19.65 & & 19.61 & 19.63 & 19.98 & 19.64 & 20.05 & 19.71 & 20.07 & 19.75 & 19.74 & 20.01 & 19.71 & & 19.69 & 19.70 & & 19.74 & 19.90 & 19.91 & 19.83 \\
\hline $\mathrm{FeO}^{\mathrm{T}}$ & 5.59 & 5.38 & & 5.52 & 5.42 & & 5.41 & 5.41 & 5.34 & 5.49 & 5.31 & 5.43 & 5.37 & 5.50 & 5.52 & 5.41 & 5.57 & & 5.40 & 5.45 & & 5.48 & 5.45 & 5.46 & 5.43 \\
\hline $\mathrm{MnO}$ & 0.28 & 0.28 & & 0.29 & 0.27 & & 0.28 & 0.26 & 0.26 & 0.27 & 0.27 & 0.28 & 0.28 & 0.28 & 0.29 & 0.27 & 0.29 & & 0.28 & 0.28 & & 0.28 & 0.28 & 0.28 & 0.27 \\
\hline $\mathrm{MgO}$ & 0.86 & 0.83 & & 0.85 & 0.83 & & 0.80 & 0.83 & 0.82 & 0.84 & 0.80 & 0.82 & 0.84 & 0.85 & 0.84 & 0.82 & 0.93 & & 0.83 & 0.92 & & 0.83 & 0.84 & 0.83 & 0.84 \\
\hline $\mathrm{CaO}$ & 1.85 & 1.88 & & 1.92 & 1.84 & & 1.89 & 1.83 & 1.89 & 1.86 & 1.86 & 1.84 & 1.89 & 1.74 & 1.75 & 1.89 & 1.80 & & 1.75 & 1.81 & & 1.79 & 1.86 & 1.88 & 1.88 \\
\hline $\mathrm{Na}_{2} \mathrm{O}$ & 8.82 & 8.85 & & 8.73 & 8.86 & & 8.80 & 8.85 & 9.09 & 8.82 & 9.09 & 8.80 & 9.04 & 8.96 & 8.99 & 9.14 & 8.96 & & 8.99 & 8.93 & & 9.04 & 9.13 & 9.02 & 9.06 \\
\hline $\mathrm{K}_{2} \mathrm{O}$ & 5.61 & 5.64 & & 5.58 & 5.63 & & 5.70 & 5.67 & 5.71 & 5.61 & 5.65 & 5.64 & 5.57 & 5.35 & 5.41 & 5.67 & 5.42 & & 5.43 & 5.50 & & 5.62 & 5.65 & 5.59 & 5.65 \\
\hline $\mathrm{P}_{2} \mathrm{O}_{5}$ & 0.28 & 0.28 & & 0.29 & 0.26 & & 0.26 & 0.27 & 0.23 & 0.28 & 0.26 & 0.28 & 0.28 & 0.27 & 0.27 & 0.26 & 0.27 & & 0.28 & 0.28 & & 0.26 & 0.29 & 0.30 & 0.28 \\
\hline $\mathrm{SO}_{2}$ & 0.08 & 0.07 & & 0.08 & 0.07 & & 0.08 & 0.08 & 0.08 & 0.08 & 0.08 & 0.08 & 0.07 & 0.06 & 0.07 & 0.07 & 0.07 & & 0.07 & 0.08 & & 0.09 & 0.07 & 0.08 & 0.08 \\
\hline F & 0.23 & 0.19 & & 0.25 & 0.22 & & 0.20 & 0.26 & 0.23 & 0.21 & 0.18 & 0.28 & 0.20 & 0.27 & 0.26 & 0.15 & 0.26 & & 0.26 & 0.31 & & 0.29 & 0.17 & 0.19 & 0.21 \\
\hline $\mathrm{Cl}$ & 0.16 & 0.15 & & 0.16 & 0.16 & & 0.16 & 0.15 & 0.16 & 0.15 & 0.16 & 0.15 & 0.15 & 0.15 & 0.14 & 0.15 & 0.15 & & 0.14 & 0.15 & & 0.16 & 0.15 & 0.16 & 0.16 \\
\hline \multicolumn{26}{|c|}{ Trace Element Concentrations (ICP-MS) } \\
\hline $\mathrm{TiO}_{2}$ (wt. \%) & 1.00 & & 1.00 & 1.02 & & 0.95 & 1.17 & 1.02 & 1.04 & 1.05 & 1.03 & & 1.00 & & & 1.04 & & 1.02 & 1.06 & 1.00 & 1.12 & 1.07 & & 0.98 & 1.03 \\
\hline Li (ppm) & 32.8 & & 30.2 & 32.5 & & 31.8 & 30.0 & 33.3 & 31.0 & 28.4 & 28.3 & & 31.8 & & & 28.6 & & 28.4 & 29.0 & 28.1 & 30.0 & 29.0 & & 30.0 & 28.8 \\
\hline $\mathrm{Be}$ & 12.7 & & 12.3 & 13.4 & & 12.5 & 12.4 & 12.9 & 11.8 & 10.1 & 10.1 & & 12.8 & & & 10.0 & & 10.0 & 10.3 & 10.0 & 10.6 & 10.3 & & 12.1 & 10.3 \\
\hline Sc & 4.34 & & 5.05 & 4.89 & & 4.92 & 4.70 & 4.46 & 4.95 & 5.04 & 4.74 & & 5.12 & & & 4.84 & & 4.80 & 5.09 & 5.09 & 5.11 & 4.86 & & 4.08 & 5.39 \\
\hline $\mathrm{v}$ & 2.20 & & 2.49 & 2.59 & & 2.10 & 4.28 & 2.62 & 2.06 & 1.86 & 1.86 & & 2.68 & & & 1.93 & & 1.91 & 2.43 & 2.34 & 2.20 & 1.97 & & 2.16 & 2.51 \\
\hline Co & 2.34 & & 2.81 & 2.62 & & 2.31 & 2.82 & 2.74 & 2.27 & 2.02 & 2.08 & & 2.78 & & & 2.18 & & 2.23 & 2.44 & 2.15 & 2.47 & 2.31 & & 2.39 & 2.23 \\
\hline $\mathrm{Zn}$ & 158 & & 160 & 159 & & 147 & 159 & 161 & 160 & 160 & 163 & & 161 & & & 161 & & 161 & 177 & 171 & 173 & 167 & & 157 & 178 \\
\hline $\mathrm{Ga}$ & 31 & & 31 & 31 & & 29 & 30 & 31 & 31 & 31 & 31 & & 30 & & & 30 & & 30 & 36 & 38 & 33 & 33 & & 31 & 39 \\
\hline $\mathrm{Rb}$ & 146 & & 143 & 147 & & 142 & 142 & 149 & 143 & 138 & 139 & & 143 & & & 137 & & 137 & 140 & 139 & 144 & 140 & & 143 & 140 \\
\hline $\mathrm{Sr}$ & 237 & & 267 & 249 & & 255 & 257 & 252 & 263 & 261 & 245 & & 251 & & & 273 & & 258 & 273 & 273 & 221 & 250 & & 272 & 252 \\
\hline Y & 85.8 & & 86.2 & 85.8 & & 80.7 & 84.0 & 85.6 & 83.0 & 76.3 & 79.8 & & 85.7 & & & 82.5 & & 78.2 & 84.9 & 81.0 & 85.6 & 79.4 & & 83.6 & 86.7 \\
\hline $\mathrm{Zr}$ & 1605 & & 1569 & 1632 & & 1541 & 1550 & 1615 & 1606 & 1592 & 1549 & & 1572 & & & 1549 & & 1533 & 1576 & 1571 & 1626 & 1573 & & 1554 & 1563 \\
\hline $\mathrm{Nb}$ & 411 & & 399 & 418 & & 394 & 399 & 415 & 415 & 414 & 407 & & 402 & & & 405 & & 402 & 408 & 402 & 421 & 410 & & 400 & 403 \\
\hline $\mathrm{Cs}$ & 2.00 & & 1.95 & 2.02 & & 1.94 & 1.95 & 2.02 & 1.91 & 1.79 & 1.78 & & 1.95 & & & 1.77 & & 1.80 & 1.89 & 1.97 & 1.85 & 1.79 & & 1.95 & 2.01 \\
\hline $\mathrm{Ba}$ & 435 & & 460 & 451 & & 461 & 456 & 454 & 465 & 460 & 436 & & 445 & & & 463 & & 455 & 465 & 475 & 404 & 438 & & 463 & 449 \\
\hline $\mathrm{La}$ & 165 & & 168 & 166 & & 156 & 165 & 166 & 164 & 153 & 161 & & 166 & & & 170 & & 158 & 175 & 167 & 174 & 161 & & 164 & 182 \\
\hline $\mathrm{Ce}$ & 319 & & 326 & 321 & & 299 & 315 & 319 & 315 & 294 & 311 & & 318 & & & 324 & & 304 & 335 & 319 & 330 & 308 & & 313 & 349 \\
\hline $\operatorname{Pr}$ & 33.9 & & 34.8 & 33.8 & & 31.8 & 33.4 & 34.0 & 33.9 & 31.6 & 33.4 & & 33.8 & & & 35.2 & & 32.7 & 36.3 & 33.6 & 36.2 & 33.4 & & 33.4 & 37.4 \\
\hline $\mathrm{Nd}$ & 113 & & 116 & 113 & & 106 & 112 & 113 & 112 & 103 & 110 & & 114 & & & 117 & & 108 & 120 & 111 & 119 & 108 & & 112 & 124 \\
\hline $\mathrm{Sm}$ & 19.1 & & 19.9 & 19.3 & & 18.0 & 19.0 & 19.2 & 19.2 & 17.7 & 18.9 & & 19.4 & & & 20.2 & & 18.7 & 20.7 & 19.0 & 20.6 & 18.6 & & 19.0 & 21.3 \\
\hline $\mathrm{Eu}$ & 3.65 & & 3.80 & 3.70 & & 3.52 & 3.71 & 3.69 & 3.73 & 3.56 & 3.63 & & 3.70 & & & 3.90 & & 3.66 & 3.93 & 3.74 & 3.83 & 3.62 & & 3.72 & 3.98 \\
\hline $\mathrm{Gd}$ & 17.0 & & 17.5 & 17.1 & & 16.0 & 16.9 & 16.9 & 15.7 & 13.6 & 14.4 & & 17.1 & & & 15.2 & & 14.3 & 15.6 & 14.5 & 15.7 & 14.4 & & 16.7 & 16.0 \\
\hline $\mathrm{Tb}$ & 2.66 & & 2.73 & 2.67 & & 2.52 & 2.63 & 2.65 & 2.48 & 2.24 & 2.34 & & 2.67 & & & 2.46 & & 2.31 & 2.49 & 2.31 & 2.55 & 2.33 & & 2.62 & 2.51 \\
\hline Dy & 14.4 & & 14.7 & 14.6 & & 13.9 & 14.3 & 14.4 & 14.0 & 12.7 & 13.3 & & 14.6 & & & 13.9 & & 13.3 & 14.0 & 13.2 & 14.4 & 13.3 & & 14.1 & 14.4 \\
\hline Но & 2.83 & & 2.86 & 2.86 & & 2.72 & 2.80 & 2.85 & 2.78 & 2.56 & 2.66 & & 2.85 & & & 2.76 & & 2.65 & 2.80 & 2.70 & 2.82 & 2.66 & & 2.77 & 2.88 \\
\hline $\mathrm{Er}$ & 7.83 & & 7.82 & 8.00 & & 7.56 & 7.71 & 7.85 & 7.81 & 7.39 & 7.60 & & 7.88 & & & 7.82 & & 7.55 & 7.98 & 7.67 & 8.08 & 7.57 & & 7.59 & 8.18 \\
\hline $\mathrm{Tm}$ & & & & & & & & & 1.17 & 1.13 & 1.16 & & & & & 1.20 & & 1.17 & 1.22 & 1.20 & 1.22 & 1.15 & & & 1.26 \\
\hline $\mathrm{Yb}$ & 7.50 & & 7.49 & 7.64 & & 7.30 & 7.33 & 7.54 & 7.50 & 7.16 & 7.28 & & 7.52 & & & 7.37 & & 7.27 & 7.51 & 7.34 & 7.61 & 7.20 & & 7.19 & 7.59 \\
\hline $\mathrm{Lu}$ & 1.16 & & 1.16 & 1.19 & & 1.15 & 1.15 & 1.18 & 1.17 & 1.12 & 1.14 & & 1.17 & & & 1.16 & & 1.14 & 1.16 & 1.13 & 1.21 & 1.12 & & 1.12 & 1.16 \\
\hline $\mathrm{Hf}$ & 31.4 & & 30.7 & 32.7 & & 30.5 & 30.8 & 31.8 & 31.9 & 31.3 & 30.6 & & 31.4 & & & 30.6 & & 30.8 & 30.4 & 29.7 & 32.3 & 30.6 & & 30.3 & 29.9 \\
\hline Та & 23.6 & & 22.8 & 24.4 & & 23.0 & 23.4 & 23.9 & 23.7 & 23.1 & 22.4 & & 23.6 & & & 22.4 & & 22.6 & 22.4 & 22.5 & 23.6 & 22.7 & & 22.7 & 22.6 \\
\hline $\mathrm{Pb}$ & 7.83 & & 5.82 & 6.13 & & 6.07 & 6.26 & - & 7.78 & 6.06 & 6.67 & & 7.53 & & & 6.74 & & 7.15 & 7.45 & 6.37 & 7.05 & 6.39 & & 5.83 & 7.46 \\
\hline Th & 31.6 & & 30.3 & 33.6 & & 32.8 & 31.2 & 31.8 & 31.8 & 29.8 & 29.6 & & 32.3 & & & 29.3 & & 29.9 & 29.2 & 29.4 & 30.6 & 29.2 & & 29.4 & 29.5 \\
\hline$\underline{\mathrm{U}}$ & 9.30 & & 8.92 & 9.81 & & 9.51 & 9.19 & 9.42 & 9.38 & 8.78 & 8.88 & & 9.53 & & & 8.69 & & 8.94 & 8.85 & 9.03 & 9.19 & 8.63 & & 8.68 & 9.11 \\
\hline
\end{tabular}


Table 2. continued

\begin{tabular}{|c|c|c|c|c|c|c|c|c|c|c|c|c|c|c|c|c|c|c|c|c|c|}
\hline & \multirow[b]{2}{*}{$\begin{array}{c}\text { Estimated } \\
\text { Uncertainty } \\
(\%)\end{array}$} \\
\hline $\begin{array}{l}\text { Eruption } \\
\text { date } \\
\text { Sample }\end{array}$ & $\begin{array}{c}\text { Dec } 1992 \\
92101 \mathrm{G}\end{array}$ & $\begin{array}{l}\text { Dec } 1992 \mathrm{I} \\
\text { Er92G }\end{array}$ & $\begin{array}{c}\text { Dec } 1993 \\
93102 \mathrm{G}\end{array}$ & $\begin{array}{c}\text { Dec } 1996 \\
\text { E96-01G }\end{array}$ & $\begin{array}{c}\text { Dec } 1996 \\
\text { ER96G }\end{array}$ & $\begin{array}{c}21 \mathrm{Dec} \\
1997 \\
97018 \mathrm{G}\end{array}$ & $\begin{array}{c}\text { Dec } 1997 \\
\text { Er97G }\end{array}$ & $\begin{array}{c}\text { Dec } 1999 \text { I } \\
1999 \mathrm{G}\end{array}$ & $\begin{array}{c}\text { Dec } 1999 \\
\text { Er } 99 \mathrm{G}\end{array}$ & $\begin{array}{c}\text { Dec } 2000 \\
\text { DEC2000G }\end{array}$ & $\begin{array}{c}\text { Dec } 2000 \\
\text { Er2000G }\end{array}$ & $\begin{array}{c}\text { Dec } 2001 \\
\text { E2001G }\end{array}$ & $\begin{array}{c}\text { Jan } 2004 \\
\text { JAN2004G }\end{array}$ & $\begin{array}{c}\text { Summary st } \\
\text { mean }\end{array}$ & $\begin{array}{l}\text { stics }(n= \\
\text { RSD } \\
(\%)\end{array}$ & median & skewness & kurtosis & minimum & maximum & \\
\hline \multirow{2}{*}{\multicolumn{21}{|c|}{ 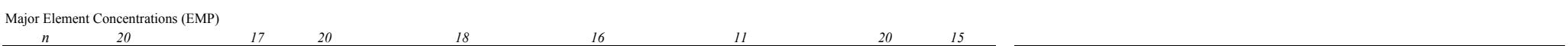 }} & \\
\hline & & & & & & & & & & & & & & & & & & & & & $n=20$ \\
\hline $\mathrm{SiO}_{2}(\mathrm{wt.} \%)$ & 54.85 & & 55.17 & $\begin{array}{l}55.12 \\
\end{array}$ & & $\begin{array}{l}55.11 \\
\end{array}$ & & $\begin{array}{c}55.00 \\
\end{array}$ & & 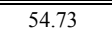 & & \begin{tabular}{c|c|}
54.94 \\
\end{tabular} & $\begin{array}{l}54.95 \\
\end{array}$ & 55.35 & 0.68 & 55.17 & 0.04 & $\begin{array}{l}-1.73 \\
\end{array}$ & 54.73 & $\begin{array}{l}55.90 \\
\end{array}$ & $\begin{array}{ll}1.0 \\
\end{array}$ \\
\hline $\mathrm{TiO}_{2}$ & 1.02 & & 1.01 & 1.02 & & 1.03 & & 1.02 & & 1.02 & & 1.02 & 1.04 & 1.01 & 1.8 & 1.02 & -0.42 & 0.00 & 0.97 & 1.05 & 3.0 \\
\hline $\mathrm{Al}_{2} \mathrm{O}_{3}$ & 19.90 & & 19.79 & 19.91 & & 19.85 & & 19.83 & & 19.93 & & 19.92 & 19.87 & 19.80 & 0.72 & 19.79 & 0.20 & -1.06 & 19.58 & 20.07 & 1.1 \\
\hline $\mathrm{FeO}^{\mathrm{T}}$ & 5.50 & & 5.42 & 5.32 & & 5.34 & & 5.38 & & 5.43 & & 5.39 & 5.45 & 5.43 & 1.3 & 5.43 & 0.39 & 0.01 & 5.31 & 5.59 & 1.3 \\
\hline $\mathrm{MnO}$ & 0.28 & & 0.27 & 0.27 & & 0.27 & & 0.28 & & 0.28 & & 0.28 & 0.27 & 0.28 & 2.4 & 0.28 & -0.46 & 0.03 & 0.26 & 0.29 & 7.2 \\
\hline $\mathrm{MgO}$ & 0.84 & & 0.82 & 0.83 & & 0.83 & & 0.83 & & 0.84 & & 0.83 & 0.82 & 0.84 & 3.2 & 0.83 & 2.1 & 5.83 & 0.80 & 0.93 & 1.2 \\
\hline $\mathrm{CaO}$ & 1.88 & & 1.88 & 1.87 & & 1.88 & & 1.86 & & 1.89 & & 1.87 & 1.90 & 1.85 & 2.6 & 1.87 & -1.20 & 0.66 & 1.74 & 1.92 & 1.6 \\
\hline $\mathrm{K}_{2} \mathrm{O}$ & 5.65 & & 5.64 & 5.64 & & 5.65 & & 5.68 & & 5.73 & & 5.67 & 5.65 & 5.61 & 1.7 & 5.64 & -1.44 & 1.36 & 5.35 & 5.73 & 1.6 \\
\hline $\mathrm{P}_{2} \mathrm{O}_{5}$ & 0.29 & & 0.28 & 0.27 & & 0.30 & & 0.31 & & 0.28 & & 0.29 & 0.27 & 0.28 & 5.7 & 0.28 & -0.82 & 2.04 & 0.23 & 0.31 & 7.2 \\
\hline $\mathrm{SO}_{2}$ & 0.07 & & 0.08 & 0.08 & & 0.08 & & 0.08 & & 0.08 & & 0.08 & 0.09 & 0.08 & 7.6 & 0.08 & -0.10 & 0.38 & 0.06 & 0.09 & 26 \\
\hline F & 0.20 & & 0.23 & 0.21 & & 0.25 & & 0.24 & & 0.20 & & 0.22 & 0.23 & 0.23 & 16 & 0.23 & 0.12 & -0.13 & 0.15 & 0.31 & 26 \\
\hline $\mathrm{Cl}$ & 0.15 & & 0.15 & 0.15 & & 0.16 & & 0.16 & & 0.16 & & 0.16 & 0.16 & 0.15 & 4.1 & 0.15 & -1.13 & 1.62 & 0.14 & 0.16 & 13 \\
\hline \multicolumn{14}{|c|}{ Trace Element Concentrations (ICP-MS) } & & & & & & & & $n=3$ \\
\hline $\mathrm{TiO}_{2}$ (wt. \%) & 1.06 & 1.07 & 1.00 & & 1.00 & & 0.97 & & 0.99 & & 1.01 & 1.02 & 1.02 & 1.03 & 4.5 & 1.02 & 1.40 & 3.17 & 0.95 & 1.17 & 4.0 \\
\hline Li (ppm) & 28.6 & 28.8 & 27.8 & & 28.3 & & 27.4 & & 28.6 & & 28.6 & 28.9 & 29.3 & 29.6 & 5.5 & 28.9 & 1.03 & 0.02 & 27.4 & 33.3 & 5.3 \\
\hline $\mathrm{Be}$ & 10.0 & 10.1 & 9.9 & & 10.0 & & 9.6 & & 10.2 & & 10.2 & 10.1 & 10.5 & 10.9 & 11 & 10.3 & 0.81 & -1.07 & 9.6 & 13.4 & 9.0 \\
\hline $\mathrm{Sc}$ & 4.75 & 5.33 & 4.81 & & 5.19 & & 4.90 & & 4.84 & & 5.00 & 4.93 & 5.26 & 4.91 & 5.8 & 4.92 & -0.97 & 1.72 & 4.08 & 5.39 & 2.3 \\
\hline $\mathrm{Zn}$ & 164 & 180 & 172 & & 175 & & 174 & & 186 & & 181 & 174 & 179 & 167 & 5.7 & 164 & 0.14 & -0.74 & 147 & 186 & 2.2 \\
\hline $\mathrm{Ga}$ & 32 & 39 & 38 & & 38 & & 37 & & 38 & & 38 & 39 & 39 & 34 & 11 & 32 & 0.35 & -1.74 & 29 & 39 & 6.8 \\
\hline $\mathrm{Rb}$ & 140 & 141 & 137 & & 138 & & 134 & & 139 & & 140 & 140 & 142 & 141 & 2.4 & 140 & 0.45 & 0.48 & 134 & 149 & 3.5 \\
\hline $\mathrm{Sr}$ & 239 & 264 & 256 & & 245 & & 245 & & 231 & & 216 & 269 & 248 & 253 & 6.0 & 252 & -0.68 & 0.28 & 216 & 273 & 2.9 \\
\hline Y & 81.4 & 82.7 & 81.8 & & 82.5 & & 77.9 & & 79.5 & & 83.9 & 80.6 & 81.8 & 82.5 & 3.4 & 82.5 & -0.33 & -0.71 & 76.3 & 86.7 & 5.8 \\
\hline $\mathrm{Zr}$ & 1569 & 1610 & 1550 & & 1603 & & 1584 & & 1576 & & 1619 & 1579 & 1601 & 1580 & 1.7 & 1576 & 0.20 & -0.96 & 1533 & 1632 & 1.9 \\
\hline $\mathrm{Nb}$ & 411 & 413 & 398 & & 405 & & 397 & & 403 & & 412 & 405 & 411 & 407 & 1.7 & 405 & 0.19 & -0.78 & 394 & 421 & 1.1 \\
\hline $\mathrm{Cs}$ & 1.79 & 2.01 & 1.97 & & 1.95 & & 1.91 & & 2.01 & & 2.01 & 1.99 & 2.06 & 1.93 & 4.7 & 1.95 & -0.61 & -0.91 & 1.77 & 2.06 & 7.8 \\
\hline $\mathrm{Ba}$ & 422 & 463 & 454 & & 436 & & 442 & & 429 & & 405 & 475 & 454 & 449 & 4.1 & 454 & -0.98 & 0.70 & 404 & 475 & 2.2 \\
\hline $\mathrm{La}$ & 166 & 172 & 171 & & 171 & & 161 & & 163 & & 175 & 166 & 169 & 166 & 3.8 & 166 & 0.16 & 0.69 & 153 & 182 & 4.7 \\
\hline $\mathrm{Ce}$ & 319 & 326 & 327 & & 328 & & 305 & & 311 & & 333 & 316 & 321 & 319 & 3.6 & 319 & 0.22 & 0.95 & 294 & 349 & 5.7 \\
\hline $\operatorname{Pr}$ & 34.6 & 34.7 & 35.0 & & 34.8 & & 32.3 & & 33.1 & & 35.3 & 33.2 & 34.4 & 34.1 & 3.9 & 33.9 & 0.39 & 0.46 & 31.6 & 37.4 & 8.1 \\
\hline $\mathrm{Nd}$ & 114 & 115 & 115 & & 115 & & 106 & & 109 & & 118 & 109 & 113 & 113 & 4.1 & 113 & 0.25 & 0.34 & 103 & 124 & 8.2 \\
\hline $\mathrm{Sm}$ & 19.6 & 19.7 & 19.7 & & 19.7 & & 18.1 & & 18.6 & & 20.1 & 18.7 & 19.5 & 19.3 & 4.3 & 19.2 & 0.33 & 0.30 & 17.7 & 21.3 & 8.6 \\
\hline Eu & 3.68 & 3.82 & 3.78 & & 3.73 & & 3.52 & & 3.59 & & 3.73 & 3.68 & 3.75 & 3.72 & 3.0 & 3.71 & 0.42 & 0.26 & 3.52 & 3.98 & 5.7 \\
\hline $\mathrm{Gd}$ & 14.8 & 14.9 & 14.9 & & 15.0 & & 13.8 & & 14.2 & & 15.2 & 14.2 & 14.8 & 15.4 & 7.5 & 15.2 & 0.32 & -1.12 & 13.6 & 17.5 & 11 \\
\hline $\mathrm{Tb}$ & 2.40 & 2.38 & 2.37 & & 2.36 & & 2.21 & & 2.29 & & 2.43 & 2.27 & 2.37 & 2.45 & 6.2 & 2.43 & 0.25 & -1.12 & 2.21 & 2.73 & 9.9 \\
\hline Dy & 13.7 & 13.7 & 13.5 & & 13.6 & & 12.7 & & 13.2 & & 13.9 & 13.1 & 13.7 & 13.8 & 4.2 & 13.9 & -0.16 & -0.80 & 12.7 & 14.7 & 6.9 \\
\hline Ho & 2.71 & 2.78 & 2.74 & & 2.74 & & 2.59 & & 2.68 & & 2.81 & 2.66 & 2.76 & 2.75 & 3.1 & 2.76 & -0.47 & -0.48 & 2.56 & 2.88 & 5.2 \\
\hline Er & 7.79 & 7.86 & 7.79 & & 7.74 & & 7.34 & & 7.71 & & 7.95 & 7.64 & 7.86 & 7.76 & 2.5 & 7.79 & -0.13 & 0.14 & 7.34 & 8.18 & 4.3 \\
\hline $\mathrm{Tm}$ & 1.17 & 1.23 & 1.21 & & 1.20 & & 1.15 & & 1.20 & & 1.24 & 1.19 & 1.24 & 1.19 & 2.9 & 1.20 & -0.07 & -0.78 & 1.13 & 1.26 & 1.3 \\
\hline $\mathrm{Yb}$ & 7.32 & 7.45 & 7.36 & & 7.37 & & 7.04 & & 7.39 & & 7.55 & 7.30 & 7.59 & 7.40 & 2.1 & 7.37 & -0.36 & -0.45 & 7.04 & 7.64 & 3.5 \\
\hline $\mathrm{Pb}$ & 6.58 & - & 6.67 & & 7.03 & & & & 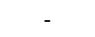 & & 7.94 & 6.86 & 7.31 & 6.83 & 10 & 6.74 & 0.12 & -1.11 & 5.82 & 7.94 & 6.0 \\
\hline Th & 29.8 & 30.5 & 29.5 & & 29.7 & & 29.2 & & 30.0 & & 30.3 & 29.1 & 30.5 & 30.4 & 4.0 & 29.9 & 1.16 & 0.54 & 29.1 & 33.6 & 6.8 \\
\hline
\end{tabular}

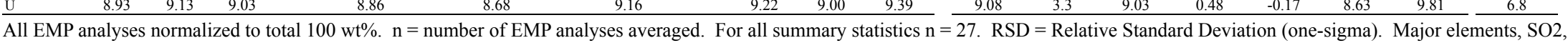
$\mathrm{F}$, and $\mathrm{Cl}$ in matrix glass were analyzed with the Cameca SX-100 3-spectrometer electron microprobe (EMP) at New Mexico Tech. A $25 \mu \mathrm{m}$ beam at $15 \mathrm{kV}$ and $10 \mathrm{nA}$ was used to prevent volatilization of $\mathrm{Na}, \mathrm{S}, \mathrm{F}$, and $\mathrm{Cl}$. Count times $=20 \mathrm{sec}$, except $\mathrm{S}=30 \mathrm{sec}, \mathrm{F}=60 \mathrm{sec}, \mathrm{Cl}=40 \mathrm{sec}$. Total Fe reported as FeO. Trace elements and TiO2 were analyzed by VG PQ ExCell quadrupole ICP-MS at Boston University following the procedures of Kelley et al. (2003). Matrix glass for trace element analysis was lightly crushed in cloth sample bags, then mafic minerals were removed using a hand magnet, and remaining crystals were removed by hand-picking under a low-power microscope. Estimated Uncertainty for EMP measurements is a statistical estimate of analytical precision determined by calculating one standard deviation of 20 analyses of rhyolite glass reference material VG-568. For trace element measurements by ICP-MS, Estimated Uncertainty was determined by performing replicate analyses on 3 samples and averaging the relative differences between the original and duplicate measurements. In this case Estimated Uncertainty is a combination of analytical uncertainty and matrix glass separate inhomogeneity. Analytical precision at BU is typically $<3 \%$. 
Table 3. Representative analyses of olivine, clinopyroxene, titanomagnetite, fluorapatite, and pyrrhotite in lava bombs erupted from Erebus volcano between December 1972 and January 2004 as determined by electron microprobe. Analytical uncertainty (2 sigma) shown in parenthesis.

\section{Titano-}

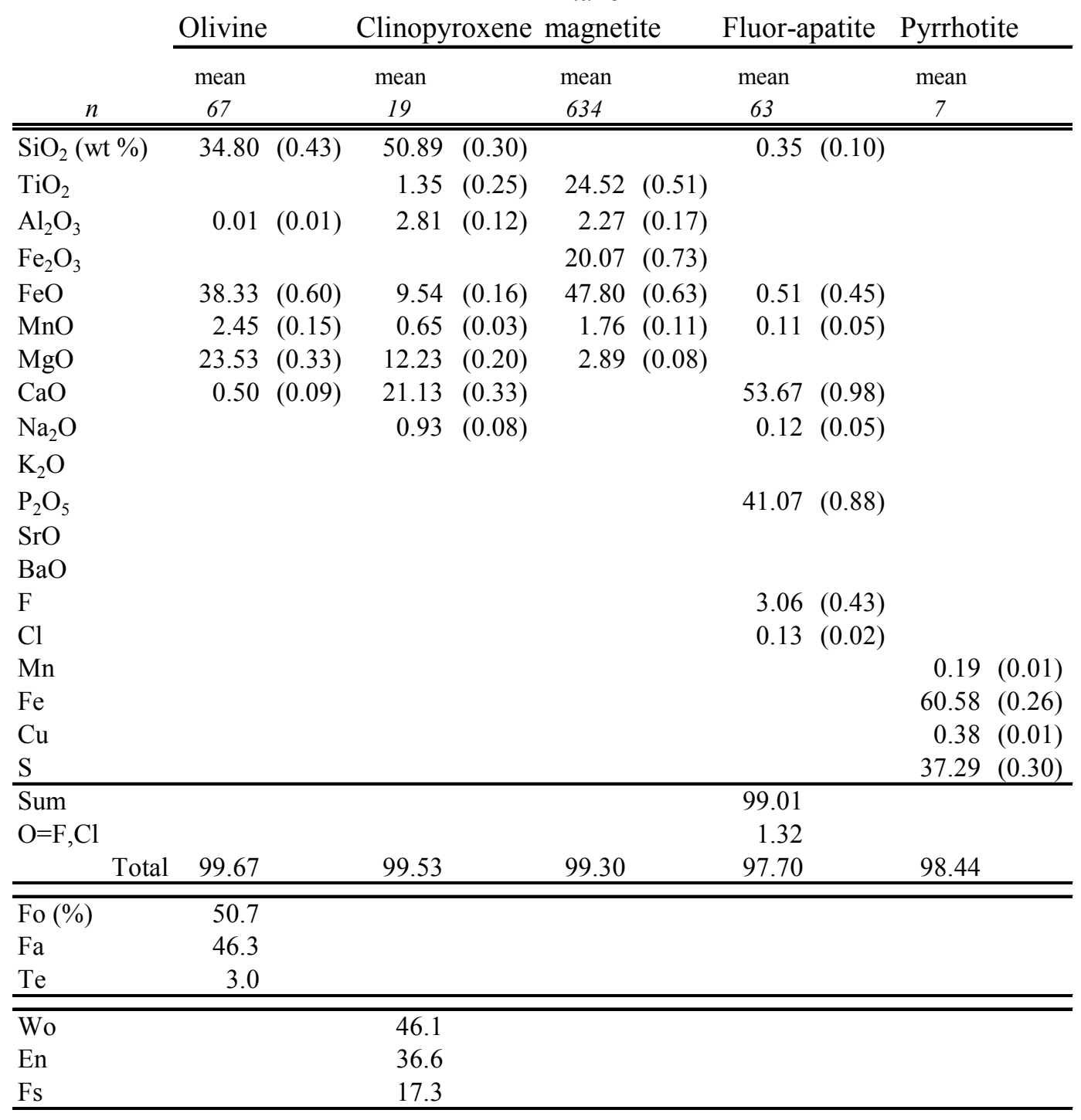

Ulvöspinel

71.5

Mineral analyses by electron microprobe showed no variation outside expected analytical precision. Therefore, mean values are taken to be representative. Analytical precision estimates are based on repeat analyses except pyrrhotite which is based on counting statistics. A focused 1 micron beam at $15 \mathrm{kV}$ and $20 \mathrm{nA}$ was used, except for fluor-apatite where a 5 micron beam was used. Count times $=20 \mathrm{sec} . \mathrm{n}=$ number of analyses averaged. Olivine endmembers: fayalite $\left(\mathrm{Fa} ; \mathrm{Fe}_{2} \mathrm{SiO}_{4}\right)$, forsterite $\left(\mathrm{Fo} ; \mathrm{Mg}_{2} \mathrm{SiO}_{4}\right)$, and tephroite $\left(\mathrm{Te} ; \mathrm{Mn}_{2} \mathrm{SiO}_{4}\right)$.

Clinopyroxene endmembers: wollastonite ( $\mathrm{Wo} ; \mathrm{Ca}_{2} \mathrm{Si}_{2} \mathrm{O}_{6}$ ), ferrosilite (Fs; $\mathrm{Fe}_{2} \mathrm{SiO}_{6}$ ), enstatite (En; $\mathrm{Mg}_{2} \mathrm{Si}_{2} \mathrm{O}_{6}$ ). Ulvöspinel content of titanomagnetite calculated following the method of Stormer (1983). 
Table 4. Representative analyses of anorthoclase feldspar in lava bombs recently erupted from Erebus volcano as determined by EMP.

\begin{tabular}{lrrrrr}
\hline & 1 & 2 & 3 & 4 & $\begin{array}{r}\text { mean } \\
(\mathrm{n}=755)\end{array}$ \\
\hline \hline $\mathrm{SiO}_{2}($ wt.\%) & 61.66 & 62.16 & 62.99 & 64.26 & 62.87 \\
$\mathrm{Al}_{2} \mathrm{O}_{3}$ & 23.73 & 23.12 & 22.68 & 21.83 & 22.81 \\
$\mathrm{CaO}$ & 4.50 & 3.77 & 3.44 & 2.30 & 3.36 \\
$\mathrm{FeO}^{\mathrm{T}}$ & 0.18 & 0.19 & 0.20 & 0.19 & 0.19 \\
$\mathrm{SrO}$ & 0.31 & 0.31 & 0.27 & 0.24 & 0.28 \\
$\mathrm{BaO}$ & 0.25 & 0.28 & 0.29 & 0.35 & 0.31 \\
$\mathrm{Na}$ & 7.30 & 7.76 & 7.69 & 7.39 & 7.57 \\
$\mathrm{~K}_{2} \mathrm{O}$ & 2.40 & 2.70 & 2.97 & 4.28 & 3.12 \\
$\mathrm{Total}$ & 100.32 & 100.27 & 100.53 & 100.75 & \\
\hline $\mathrm{Ab} \%)$ & 64.2 & 66.8 & 66.6 & 65.5 & 65.8 \\
$\mathrm{An}$ & 21.9 & 17.9 & 16.4 & 11.3 & 16.2 \\
Or & 13.9 & 15.3 & 17.0 & 24.9 & 17.9 \\
\hline
\end{tabular}

The mean of all analyses $(n=755)$ is taken as representative of the anorthoclase solid composition and is used in models. Anorthoclase feldspar endmembers: anorthite (An; $\left.\mathrm{CaAl}_{2} \mathrm{Si}_{2} \mathrm{O}_{8}\right)$, albite $\left(\mathrm{Ab} ; \mathrm{NaAlSi}_{3} \mathrm{O}_{8}\right)$, orthoclase (Or; $\left.\mathrm{KAlSi}_{3} \mathrm{O}_{8}\right)$. A $10 \mu \mathrm{m}$ beam at $15 \mathrm{kV}$ and $20 \mathrm{nA}$ was used. Count times $=90 \mathrm{sec}$. Based on counting statistics estimated analytical precision (1 sigma) for determinations are: $\mathrm{SiO}_{2} \pm 1 \% ; \mathrm{Al}_{2} \mathrm{O}_{3} \pm 1 \%$; $\mathrm{CaO} \pm 2 \% ; \mathrm{FeO}^{\mathrm{T}} \pm 7 \% ; \mathrm{SrO} \pm 7 \% ; \mathrm{BaO} \pm 8 \% ; \mathrm{Na}_{2} \mathrm{O} \pm 2 \% ; \mathrm{K}_{2} \mathrm{O} \pm 2 \%$. 
Table 5. Modal mineralogy of recently erupted lava bombs calculated by mass-balance.

\begin{tabular}{lrrrrrrr}
\hline Mineral proportions (wt.\%) & 25724WR & 2E2WR & 77016WR & 78325WR & 25721WR & 77015WR & 97018WR \\
\hline \hline matrix glass & 65.7 & 68.7 & 66.6 & 66.5 & 66.8 & 75.9 & 65.5 \\
anorthoclase feldspar & 31.2 & 28.7 & 30.9 & 30.1 & 30.6 & 21.6 & 30.6 \\
titanomagnetite & 1.2 & 1.0 & 0.9 & 0.9 & 0.9 & 0.9 & 1.7 \\
olivine & 0.8 & 0.6 & 0.6 & 1.3 & 0.4 & 0.6 & 1.3 \\
clinopyroxene & 0.5 & 0.5 & 0.5 & 0.7 & 0.8 & 0.6 & 0.4 \\
fluor-apatite & 0.5 & 0.5 & 0.5 & 0.5 & 0.5 & 0.5 & 0.6 \\
\hline$\Sigma_{\mathrm{r}}^{2}$ & 0.05 & 0.09 & 0.09 & 0.02 & 0.14 & 0.12 & 0.08 \\
\hline
\end{tabular}

Mineral modes calculated by major element least squares mass balance using whole rock lava bomb analyses from Caldwell and Kyle (1994) and Eschenbacher (sample 97018WR; 1998) and mineral compositions from this study. $\Sigma \mathrm{r}^{2}=$ sum of squares of residuals. 